\title{
What Determines the Composition of International Bank Flows?
}

Niepmann, Friederike, and Cornelia Kerl

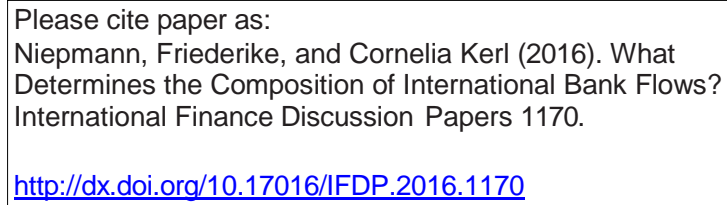

Niepmann, Friederike, and Cornelia Kerl (2016). What Determines the Composition of International Bank Flows? International Finance Discussion Papers 1170.

http://dx.doi.org/10.17016/IFDP.2016.1170

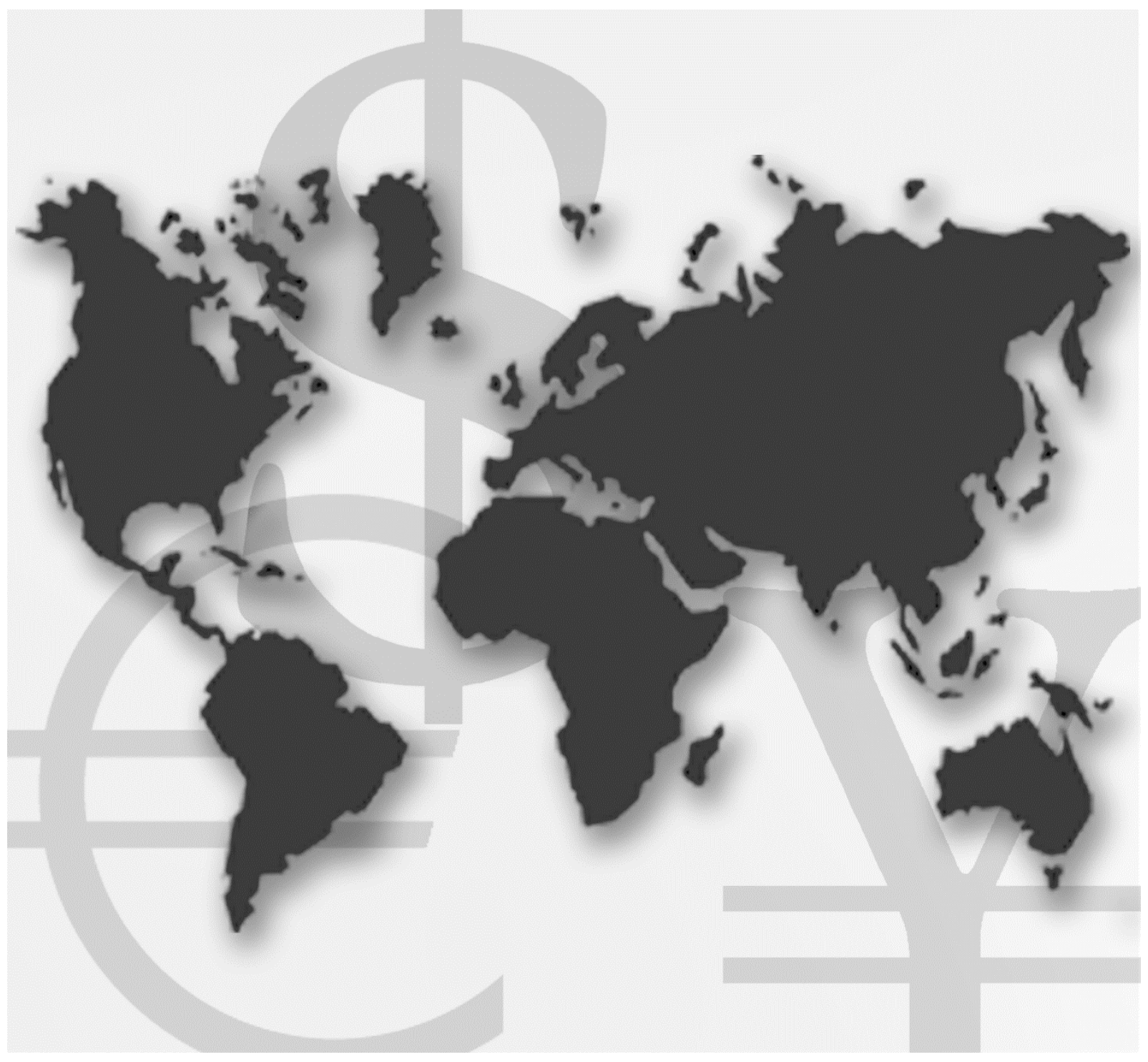

\section{International Finance Discussion Papers}

Board of Governors of the Federal Reserve System

Number 1170

June 2016 


\section{Board of Governors of the Federal Reserve System \\ International Finance Discussion Papers}

Number 1170

June 2016

\section{What Determines the Composition of International Bank Flows?}

Cornelia Kerl

Friederike Niepmann

NOTE: International Finance Discussion Papers are preliminary materials circulated to stimulate discussion and critical comment. References to International Finance Discussion Papers (other than an acknowledgment that the writer has had access to unpublished material) should be cleared with the author or authors. Recent IFDPs are available on the Web at www.federalreserve.gov/pubs/ifdp/. This paper can be downloaded without charge from the Social Science Research Network electronic library at www.ssrn.com. 


\title{
What Determines the Composition of International Bank Flows?*
}

\author{
Cornelia Kerl** and Friederike Niepmann***
}

\begin{abstract}
This paper studies how frictions to foreign bank operations affect the sectoral composition of banks' foreign positions, their funding sources and international bank flows. It presents a parsimonious model of banking across borders, which is matched to bank-level data and used to quantify cross-border frictions. The counterfactual analysis shows how higher barriers to foreign bank entry alter the composition of international bank flows and may reverse the direction of net interbank flows. It also highlights that interbank lending and lending to non-banking firms respond differently to changes in foreign and domestic conditions. Ultimately, the analysis suggests that policies that change cross-border banking frictions and, thereby, the composition of banks' foreign activities affect how shocks are transmitted across borders.
\end{abstract}

Keywords: global banks, interbank market, international bank flows, cross-border banking JEL-Codes: F21, F23, F30, G21

\footnotetext{
${ }^{*}$ We thank Pierre-Olivier Gourinchas, Galina Hale, Katheryn Russ, Tim Schmidt-Eisenlohr, Vania Stavrakeva, Frederic Boissay and two anonymous referees for their helpful comments. This paper was prepared for the DNB/IMF conference "International Banking: Microfoundations and Macroeonomic Implications".

**Deutsche Bundesbank, Wilhelm-Epstein Str. 14, 60431 Frankfurt am Main, Germany. E-Mail: Cornelia.Kerl@bundesbank.de. The views in this paper are solely the responsibility of the author(s) and should not be interpreted as reflecting the views of the the Deutsche Bundesbank, their staff, or of any other person associated with the Deutsche Bundesbank.

${ }^{* * *}$ The author is a staff economist in the Division of International Finance, Board of Governors of the Federal Reserve System, Washington, D.C. 20551 U.S.A. E-Mail: Friederike.Niepmann@frb.gov. The views in this paper are solely the responsibility of the author(s) and should not be interpreted as reflecting the views of the Board of Governors of the Federal Reserve System or of any other person associated with the Federal Reserve System.
} 


\section{Introduction}

Global banks are active around the world, lending to banks and firms abroad. While loans to foreign banks and loans to foreign firms were equally large 20 years ago, the largest share of foreign lending today goes to foreign non-banking firms. ${ }^{1}$ Figure 1 illustrates this by showing the composition of banks' foreign activities according to data from the Bank for International Settlements (BIS). The top chart depicts bank claims of around 25 BIS reporting countries on foreign parties, which are split into claims on foreign banks, foreign firms and foreign governments. As the bottom chart highlights, claims on foreign firms as a share of total international claims have been increasing since 1999 and account for roughly 55 percent of international claims today.

This paper provides a parsimonious model of banking across borders that can address these developments, showing how barriers to foreign bank operations affect the sectoral composition of bank activities. Based on detailed bank-level data from the Deutsche Bundesbank to support the model, the paper highlights that different types of bank activities are interconnected and are often substitutes, for example, lending by banks on the interbank market and lending to foreign firms. When the impediments to foreign bank operations decline, bank lending to foreign firms rises, while lending to foreign banks falls. ${ }^{2}$

These results are relevant for the current debate around global banking. Since the 2007/2008 financial crisis, when international bank flows collapsed, the foreign operations of banks have been under great scrutiny from policy makers, which have considered regulating foreign bank activities. To understand the implications of possible restrictions on global banking, it is key to have an integrated view of banks' foreign operations. The model in this paper allows for this by explicitly incorporating an international interbank market, cross-border lending by banks to foreign firms as well as entry of foreign banks into local banking markets into a single theoretical framework. This is in contrast to existing frameworks in the international banking literature, which focus on only one or two of these activities. ${ }^{3}$

The paper starts by presenting a closed economy model, in which the interbank market is a means to reallocate funds from the less efficient to the more efficient banks. ${ }^{4}$ Banks have to monitor firms when they extend a loan, which is costly. Because banks have equal amounts of deposits but face different monitoring costs, it is optimal that funds are redistributed from the high-cost to the low-cost banks. In the open economy model, banks can lend and borrow on the international interbank market and they can engage in cross-border lending to firms or establish foreign affiliates abroad for a fixed cost. A foreign affiliate allows the bank to

\footnotetext{
${ }^{1}$ Firms refer to non-banking firms as opposed to banks in this paper.

${ }^{2}$ The model provides a potential explanation for the patterns in figure 1 but the chart should be seen as mainly motivational. The paper does not test in how far the model generates the observed patterns in the chart but instead uses German bank-level data to support the proposed theory.

${ }^{3}$ In Bruno and Shin (2015), intra-bank and interbank lending are isomorphic. In Niepmann (2015), interbank funding, cross-border deposit taking and borrowing from foreign affiliates are isomorphic. Niepmann (2013) abstracts from interbank lending. In de Blas and Russ (2013), cross-border lending and lending through foreign affiliates are considered as separate scenarios. Corbae and D'Erasmo (2010) study banking industry dynamics without allowing for interbank lending. Building on the aforementioned work, Corbae and D'Erasmo (2014) introduce interbank lending into a closed economy without considering foreign bank operations.

${ }^{4}$ This in line with in the modeling approach in Boissay (2011), for example.
} 
decrease variable transaction costs from operating abroad and to raise additional funds from foreign depositors. In equilibrium, banks lend to and borrow from each other as well as to and from foreign and domestic firms/depositors so that monitoring costs and efficiency losses due to cross-border frictions are minimized and the return on loans is maximized.

We apply the model to data from the Deutsche Bundesbank with detailed information on German banks' foreign operations and balance sheets. By taking a structural approach and matching the model to the data, we can study the quantitative responses of international bank activities to varying underlying structural parameters. In a first step, we exploit key structural equations of the model to learn about the barriers that banks face abroad. We derive simple equations that relate banks' domestic and cross-border loans to their efficiency and bank entry barriers. With the German data at hand, these equations can be used to quantify the frictions. In particular, we obtain for each country in which German banks operate the variable costs of operating there as well as the fixed costs of lending cross-border to non-banking firms and of establishing affiliates in that market. The calculated cost parameters for various host countries are strongly correlated with proxies of countries' openness. The model prediction that larger banks tend to be borrowers while smaller banks tend to be lenders on the international interbank market also holds in the data.

Based on the parameters obtained from the previous exercise, we simulate a two-country version of the model to analyze and quantify how bank entry barriers affect the composition of foreign bank activities. The counterfactual analysis is for German bank operations in the US. The model matches the Bundesbank data well, in particular the observed loans of German banks to US firms as well as net interbank flows between the two countries. Different scenarios are compared to the calibrated baseline economy. We consider the case in which banks can lend and borrow on the international interbank market but not from foreign firms and depositors (scenario i). We also study a 10 percent reduction in the fixed cost of establishing a foreign affiliate in the US compared to the baseline economy (scenario ii).

The counterfactual analysis shows how impediments to foreign bank operations affect the composition of banks' foreign assets, their funding sources as well as the composition of crossborder bank flows between countries. In the baseline economy, consistent with the data, German banks' operate both cross-border from home as well through affiliates in the US. To fund these activities, they use domestic deposits, foreign deposits and funds borrowed on the international interbank market. When cross-border frictions rise and eventually become prohibitively high in scenario (i), capital only flows between the two countries through the international interbank market. As a result, German banks extend loans only to US banks but not to US firms. These loans are exclusively funded with domestic deposits. Total loans to US firms decline as German banks redirect some of their lending back to domestic firms. Flows on the international interbank market reverse and Germany turns from being a net borrower from US banks to being a net lender.

Effects are different when the cost of establishing a foreign affiliate in the US falls (scenario ii) compared to the baseline economy. German banks expand their lending to US non-banking firms, which they fund both through the interbank market and through raising more US deposits. When parent banks provide a large fraction of funding to their affiliates, both the 
volume of net intrabank flows between German parent banks and their US affiliates as well as net interbank flows between Germany and the US rise (German banks continue to be net borrowers from US banks).

Together the counterfactual analysis highlights how the barriers to foreign bank operations affect the quantity of domestic credit, who supplies credit (domestic versus foreign banks) and the sources of funding for domestic credit. Why does this matter? A growing number of empirical papers documents that banks do not uniformly adjust their activities in response to balance sheet shocks. Lending by foreign-owned banks in a country appears to be less stable than lending by domestically-owned banks. ${ }^{5}$ At the same time, there is evidence that funding provided on the interbank market is more volatile than funding provided by parent banks. ${ }^{6}$ Policies that alter the barriers to foreign bank operations may therefore affect the availability and volatility of domestic credit, with ultimate consequences for real activity. ${ }^{7}$ For example, higher barriers to foreign bank entry may make a country rely less on credit extended by foreign banks but, at the same time, domestic banks may increase their borrowing on international interbank markets. It is not clear whether domestic credit becomes less or more prone to foreign shocks and the effects for domestic financial stability are ambiguous.

This paper does not address such dynamic issues directly. However, by detailing theoretically the link between cross-border banking frictions and the composition of international bank flows, it provides a key building block that should be integrated into richer international macro models to study the implications of banking sector integration for financial stability. ${ }^{8}$ The quantitative results obtained from the structural exercise can also serve as inputs for future work in this direction.

\section{A Model of International Banking}

The model presented in this papers is inspired by the theoretical framework in Niepmann (2013). In contrast to the aforementioned paper, it incorporates an international interbank market as the basis for studying the implications of impediments to foreign entry on the sectoral composition of banks' foreign activities.

\footnotetext{
${ }^{5}$ See de Haas and van Lelyveld (2010), Ongena et al. (2013), and de Haas and van Lelyveld (2014). Foreign bank ownership can also provide support in a domestic crisis as documented in Jeon et al. (2013), Popov and Udell (2012), and de Haas and van Lelyveld (2006).

${ }^{6}$ See Schnabl (2012), Reinhardt and Riddiough (2014), and McCauley et al. (2012). Additional work suggests that local lending by affiliates is more stable than cross-border lending by the parent banks. See Milesi-Ferretti and Tille (2011), Cetorelli and Goldberg (2011), de Haas and van Horen (2013), Kamil and Rai (2010), Duewel et al. (2011).

${ }^{7}$ Cuts in the supply of credit by banks have been shown to have adverse effects on production and employment. See, e.g., Khwaja and Mian (2008), Rosengren and Peek (2000), and Chodorow-Reich (2014).

${ }^{8}$ For papers that introduce global banks in international macro, see, e.g., Kollmann (2013), Olivero (2010), Kollmann et al. (2011), and Greenwood et al. (2013).
} 


\subsection{Closed economy}

In the closed economy, there are a mass $M$ of bankers and $K$ units of depositor capital. Each banker has $d=K / M$ units of deposits and can lend the collected funds to the aggregate production sector, which yields an exogenous return $R>1$ per unit invested. ${ }^{9}$ Bankers incur costs from monitoring the firms they lend to. This cost differs across bankers, who draw an efficiency parameter $a$ from a distribution $g(a)$ with support $[\underline{a}, \bar{a}]$ and mean $a^{\prime}$. A higher value implies that the banker faces lower monitoring costs and is more efficient. ${ }^{10}$ Bankers face decreasing returns to scale, that is, total monitoring costs increase in the bank's credit volume. ${ }^{11}$ The monitoring costs $c$ of a banker with efficiency $a$ are given by:

$$
c(a)=\frac{1}{a} h(z)
$$

where $h(z)$ is a continuous and twice differentiable function with $h^{\prime}(z)>0$ and $h^{\prime \prime}(z)>0$ and $z$ is the total capital lent to firms by the banker with efficiency $a$.

Bankers can lend and borrow without costs from each other on the interbank market at the endogenous rate $R^{I}$. The profits of the banker with efficiency $a$ are therefore:

$$
\pi(a)=R z-\frac{1}{a} h(z)-R^{I}(z-d)
$$

Each banker chooses $z$ to maximize profits. The first-order condition implies:

$$
h^{\prime}(z)=a\left(R-R^{I}\right) .
$$

Given the assumed properties of $h(z)$, there exists a unique solution to each banker's lending volume $z$, which increases in the return to capital $R$ and the banker's efficiency $a$ and decreases in the interbank lending rate $R^{I}$. In the remainder of this paper, we will assume that $h(z)=\frac{1}{2} z^{2}$, which delivers $z=a\left(R-R^{I}\right)$.

Capital market clearing requires that banks invest the total depositor capital $K$ in the production sector:

$$
M \int_{\underline{a}}^{\bar{a}} z(a) g(a) d a=K .
$$

\footnotetext{
${ }^{9}$ The supply of domestic deposits is assumed to be fixed and the same for each bank. This assumption simplifies the model greatly because it eliminates any additional source of heterogeneity on the liability side of banks' balance sheets. Interbank borrowing and lending is simply the gap between banks' optimal loan volumes (which differ across banks) and deposits (which are the same for each bank) and is not an endogenous choice per se. To model the liability side of banks' balance sheets more explicitly, one could assume, for example, that bankers compete for deposits, facing convex costs of raising deposits. The deposit rate would then be a function of the interbank lending rate and the cost of raising deposits. The size of domestic deposits on banks' balance sheets would vary across banks. As we show later based on German bank-level data, the model predictions regarding banks' net interbank lending and borrowing hold in the data. Thus, the model captures key features of banks' funding composition even without more sophisticated modeling of the deposit side.

${ }^{10}$ Heterogeneity in the cost of financial intermediation is also modeled in de Blas and Russ (2010) and de Blas and Russ (2013).

${ }^{11}$ This could be rationalized as follows: As the size of a banker's loan portfolio increases, the quality of the borrowers goes down, reflected in higher per unit monitoring costs. Alternatively, organizational complexity may increase with bank size and lead to higher operating costs.
} 
Plugging in $\mathrm{z}$, we obtain:

$$
\int_{\underline{a}}^{\bar{a}} a\left(R-R^{I}\right) g(a) d a=\frac{K}{M} .
$$

Solving for $R^{I}$ yields:

$$
R^{I}=R-\frac{K}{M} \frac{1}{\int_{\underline{a}}^{\bar{a}} a g(a) d a}=R-\frac{K}{M} \frac{1}{a^{\prime}},
$$

where $a^{\prime}=E(a)=\int_{\underline{a}}^{\bar{a}} a g(a) d a$ reflects the average efficiency of bankers in the economy. Expression (6) shows that the interbank lending rate in the economy is a function of the return on loans and the efficiency of the economy's banking sector. The larger the return $R$ on loans and the lower the bankers' average monitoring costs are, the higher is the equilibrium interbank lending rate $R^{I}{ }^{12}$ This rate also depends on the number of bankers relative to deposits in the economy. The more bankers there are relative to deposits, the lower are the deposits that a single banker has, the tougher is the competition for funds and the higher is the interbank rate.

\subsection{Open economy with international interbank lending}

In the open economy, there are $N$ countries. Countries differ in the return $R$ on loans, their size $K$, the mass of bankers $M$ they host, and in their banking sector efficiencies.

As the first scenario, we consider the case in which there is an international interbank market that allows banks to lend and borrow across borders. Banks cannot lend to foreign firms directly so that interbank lending is the only channel through which capital can be reallocated from one country to the other.

An equilibrium requires that the international interbank market clears, that is, the capital lent to firms in all countries must equal the world capital endowment:

$$
\sum_{i=1}^{N} K_{i}=\sum_{i=1}^{N} M_{i} \int_{\underline{a}_{i}}^{\bar{a}_{i}} a_{i}\left(R_{i}-R^{I}\right) g_{i}\left(a_{i}\right) d a_{i} .
$$

Solving for $R^{I}$ delivers the following expression:

$$
R^{I}=\frac{\sum_{i=1}^{N} M_{i} R_{i} a_{i}^{\prime}-\sum_{i=1}^{N} K_{i}}{\sum_{i=1}^{N} M_{i} a_{i}^{\prime}},
$$

where $a_{i}^{\prime}=E\left(a_{i}\right)=\int_{\underline{a}_{i}}^{\bar{a}_{i}} a_{i} g_{i}\left(a_{i}\right) d a_{i}$. The interbank lending rate in the open economy thus depends on relative country sizes and returns on loans as well as the average efficiency of banking sectors and the mass of bankers in each country. The same factors also determine the allocation of capital across countries. The capital flow into country $i$, denoted by $K_{i}^{X}$, is given

\footnotetext{
${ }^{12}$ It is assumed that parameters are such that investment and financial intermediation are beneficial in the economy so that all funds are in fact invested in projects. This requires that monitoring costs are not too high so that $R-1 / a^{\prime}>1$.
} 
by:

$$
K_{i}^{X}=\frac{\sum_{j \neq i}^{N}\left(R_{i}-R_{j}\right) M_{i} M_{j} a_{i}^{\prime} a_{j}^{\prime}+M_{i} a_{i}^{\prime} \sum_{j \neq i}^{N} K_{j}-K_{i} \sum_{j \neq i}^{N} M_{j} a_{j}^{\prime}}{\sum_{j=1}^{N} M_{j} a_{j}^{\prime}}
$$

Assuming that $N=2$ and $M_{i}=K_{i}$, this expression reduces to:

$$
K_{i}^{X}=\frac{\sum_{j \neq i}^{N}\left(R_{i}-R_{j}\right) K_{i} K_{j} a_{i}^{\prime} a_{j}^{\prime}+\sum_{j \neq i}^{N}\left(a_{i}^{\prime}-a_{j}^{\prime}\right) K_{i} K_{j}}{\sum_{j=1}^{N} K_{j} a_{j}^{\prime}} .
$$

It shows that, in equilibrium, capital is allocated such that differences in monitoring costs and differences in returns are optimally traded off. The larger the return on loans is in a country relative to the other countries and the more efficient a country's banks are relative to other banking sectors, the larger the capital flow is into that country. Every additional unit of capital that is employed in production in country $i$ must be intermediated by banks in country $i$ (foreign banks cannot lend to firms in country $i$ ). Thus a more efficient banking sector in country $i$ implies that the economic loss from monitoring an additional firm (or unit of capital) there is lower than in other countries. As a result, it is beneficial to employ more capital in production in country $i$, even when the return on loans is the same in all countries.

\subsection{Open economy with cross-border lending and affiliate lending}

In the second open economy scenario, banks can lend to firms abroad, in addition to lending and borrowing on the international interbank market. Lending to firms abroad is costly, however. Banks from country $j$ that lend cross-border to firms in country $i$ have to pay the fixed cost $f_{i j}^{X}>0$. These costs can be interpreted as fixed costs associated with acquiring information about the business environment abroad, for example, or about establishing client relationships there.

It is further assumed that banks can grow their balance sheet if they lend to firms abroad. Specifically, we model the profit function of a banker from country $j$ that lends to firms in country $i \in N$ as follows:

$$
\pi_{j}\left(a_{j}\right)=\sum_{i=1}^{N}\left(R_{i} z_{i j}-\frac{1}{\phi_{i j}\left(a_{j}\right) \delta_{i j}^{X} a_{j}} h\left(z_{i j}\right)-R^{I} z_{i j}-f_{i j}^{X}\right)+R^{I} d,
$$

where $0 \leq \delta_{i j}^{X}<1, f_{j j}^{X}=0, \delta_{j j}^{X}=1$ and $\phi_{j j}\left(a_{j}\right)=1$. In this formulation, banks' monitoring costs at home and abroad are separable so that their decision to engage in cross-border lending is independent of lending at home and banks seek to replicate their business abroad. This assumption can be motivated by "love for variety" in loans, for example. If banks can offer differentiated loans, then each bank specializes in providing a particular type of loan or in lending to a particular type of firm/sector, and it is optimal that every bank operates in every country for sufficiently low fixed costs. ${ }^{13}$

\footnotetext{
${ }^{13} \mathrm{An}$ alternative interpretation of our assumption is that banks want to invest at home and abroad in order to
} 
$\delta_{i j}^{X}$ reflects inversely the efficiency loss of a banker from country $i$ that lends to firms in country $j$ cross-border. This efficiency loss can be due to information frictions, since it may be harder for firms to access information about clients abroad. It can also reflect greater transaction costs. ${ }^{14}$ We allow the efficiency loss to differ across banks as some banks may have an advantage/disadvantage in operating in certain countries. Bankers draw a parameter $\phi_{i j}\left(a_{j}\right)$ from a distribution $m(\phi)$ with mean 1 and choose to lend to firms in country $i$ if:

$$
\pi_{i j}^{X}\left(a_{j}\right)=R_{i} z_{i j}^{X}-\frac{1}{\phi_{i j}\left(a_{j}\right) \delta_{i j}^{X} a_{j}} h\left(z_{i j}^{X}\right)-R^{I} z_{i j}^{X}-f_{i j}^{X} \geq 0,
$$

where $z_{i j}^{X}=a_{j} \phi_{i j}\left(a_{j}\right) \delta_{i j}^{X}\left(R_{i}-R^{I}\right)$. The banker who breaks even on the lending business in country $i$ is then given by:

$$
\phi_{i j}\left(a_{j}\right) a_{i j}^{X}=\tilde{a}_{i j}^{X}=\frac{2 f_{i j}^{X}}{\left(R_{i}-R^{I}\right)^{2} \delta_{i j}^{X}} .
$$

The lower the fixed cost $f_{i j}^{X}$ and the efficiency loss from operating cross-border $\delta_{i j}^{X}$ are, the lower is the efficiency of the banker that makes zero profits on the cross-border operations in country $i \tilde{a}_{i j}^{X}$.

Instead of lending cross-border, banks can open up affiliates in the foreign country $i$ for a fixed cost $f_{i j}^{F}>f_{i j}^{X}-K_{i} / M_{i} \max \left\{R_{1}, R_{2}, \ldots, R_{N}\right\} .{ }^{15}$ A foreign affiliate has the advantage of lowering banks' monitoring costs when lending abroad. Banks still face a friction in the form of $\delta^{F} \leq 1$ but the friction is assumed to be lower than for cross-border operations, i.e. $1 \geq \delta_{i j}^{F}>\delta_{i j}^{X}$. Having an affiliate also allows banks to raise foreign deposits. ${ }^{16}$ If a banker of type $a_{j}$ establishes an affiliate in country $i$, his profits that come solely from operations in that country are:

$$
\pi_{i j}^{F}\left(a_{j}\right)=R_{i} z_{i j}^{F}-\frac{1}{\phi_{i j}\left(a_{j}\right) a_{j} \delta_{i j}^{F}} h\left(z_{i j}^{F}\right)-R^{I} z_{i j}^{F}-f_{i j}^{F}+R^{I} d_{i j},
$$

where $z_{i j}^{F}=\phi_{i j}\left(a_{j}\right) a_{j} \delta_{i j}^{F}\left(R_{i}-R^{I}\right)$. A banker chooses to open up an affiliate abroad if the resulting profits are positive and higher than the profits from lending cross-border. The banker who is indifferent between cross-border lending and operating through an affiliate is found by setting profits under cross-border lending to market $i$ equal to profits with an affiliate in country $i$ :

$$
\phi_{i j}\left(a_{j}\right) a_{i j}^{F}=\tilde{a}_{i j}^{F}=\frac{2}{\left(R_{i}-R^{I}\right)^{2}} \frac{1}{\delta_{i j}^{F}-\delta_{i j}^{X}}\left(f_{i j}^{F}-f_{i j}^{X}-R^{I} d_{i j}\right) .
$$

diversify. If risk is reduced, banks may be able to increase their leverage and, thereby, the size of their balance sheets. Love for variety in loans is modeled in de Blas and Russ (2010).

${ }^{14}$ There is empirical evidence that information frictions and distance affect banks' foreign activities. See Buch (2003), Focarelli and Pozzolo (2005) and Degryse and Ongena (2005).

${ }^{15}$ The condition insures that the fixed cost of establishing an affiliate $f_{i j}^{F}$ net of the benefits from raising deposits in country $i\left(R^{I} d_{i}\right)$ is always larger than the fixed cost of cross-border lending.

${ }^{16}$ An affiliate in our framework can be interpreted both as a branch and a subsidiary, although the interpretation as a subsidiary is preferred. Branches often facilitate lending to or borrowing from foreign banks or wholesale investors. In contrast, subsidiaries make it easier for banks to raise retail deposits in a foreign market. The model could distinguish between branch and subsidiary by assuming that a branch implies $\delta_{i j}^{X}=\delta_{i j}^{F}$ whereas a subsidiary allows banks to compete for foreign deposits. 
$\tilde{a}_{i j}^{F}$ depends on the relative attractiveness of the two modes of entry. The lower $f_{i j}^{F}$ and the higher $\delta_{i j}^{F}$ are compared to $\delta_{i j}^{X}$ and $f_{i j}^{X}$, the lower is $\tilde{a}_{i j}^{F}$. $\tilde{a}_{i j}^{F}$ is also a function of the interbank rate. The higher the interbank rate $R^{I}$ is, the more attractive it is to raise additional deposits abroad and the more bankers establish an affiliate in country $i$, resulting in a lower $\tilde{a}_{i j}^{F}$.

The open economy model is closed by two equilibrium conditions. First, the capital invested in each country by all banks must equal the world capital endowment:

$$
\sum_{i=1}^{N} K_{i}=\sum_{i=1}^{N} \tilde{K}_{i}
$$

where

$$
\tilde{K}_{i}=M_{i} \int_{\underline{a}_{i}}^{\bar{a}_{i}} z_{i i} g_{i}\left(a_{i}\right) d a_{i}+\sum_{j=1, j \neq i}^{N} M_{j} \int_{\tilde{a}_{i j}^{X}}^{\tilde{a}_{i j}^{F}} z_{i j}^{X} n_{i j}\left(\tilde{a}_{i j}\right) d \tilde{a}_{i j}+\sum_{j=1, j \neq i}^{N} M_{j} \int_{\tilde{a}_{i j}^{F}}^{\tilde{a}_{i j}} z_{i j}^{F} n_{i j}\left(\tilde{a}_{i j}\right) d \tilde{a}_{i j} .
$$

$n_{i j}\left(\tilde{a}_{i j}\right)$ denotes the joint distribution of $\phi_{i j}\left(a_{j}\right) a_{j}$ and $\overline{\tilde{a}}_{i j}$ is its upper support.

Second, bankers with affiliates in a country compete for local deposits. Each banker obtains the capital stock divided by the mass of bankers that compete for the deposits. The following condition must hold for each country $i$ :

$$
K_{i}=M_{i} \int_{\underline{a}_{i}}^{\bar{a}_{i}} d_{i i} g_{i}\left(a_{i}\right) d a_{i}+\sum_{j=1, j \neq i}^{N} M_{j} \int_{\tilde{a}_{i j}^{F}}^{\overline{\tilde{a}}_{i j}} d_{i j} n_{j}\left(\tilde{a}_{i j}\right) d \tilde{a}_{i j}
$$

Because domestic bankers and foreign bankers with affiliates in market $i$ raise the same amount of deposits, implying $d_{i i}=d_{i j}=d_{i}$. Solving for $d_{i}$ yields:

$$
d_{i}=\frac{K_{i}}{M_{i}+\sum_{j=1, j \neq i}^{N} M_{j} \int_{\tilde{a}_{i j}^{F}}^{\tilde{a}_{i j}} n_{j}\left(\tilde{a}_{i j}\right) d \tilde{a}_{i j}} .
$$

Proposition 1 There exists a unique solution to the open economy if $f_{i j}^{F}>f_{i j}^{X}-K_{i} / M_{i}$ $\max \left\{R_{1}, R_{2}, \ldots, R_{N}\right\}$.

With cross-border and affiliate lending, the equilibrium interbank lending rate increases compared to the previous scenario with international interbank lending only. Because the more efficient banks extend loans to firms abroad in addition to lending domestically, their demand for interbank funds increases. For smaller banks to be willing to provide these funds, the interbank lending rate must go up.

Moreover, the tradeoff between allocating capital efficiently and minimizing monitoring costs is alleviated, since banks can now lend directly to foreign firms and the intermediation does not have to be done by the domestic banks. As a consequence, more capital flows into the country with the higher return to capital. We revisit the implications of openness to foreign bank entry for net capital flows and the composition of banks' foreign activities in section 4 . 


\section{The Barriers to German Banks's Foreign Operations}

The model provides a structural framework that can be applied to the data and used to back out the parameters $\delta_{i j}^{X}, f_{i j}^{X}, \delta_{i j}^{F}$ as well as $f_{i j}^{F}$. In this section, we describe our strategy to obtain values for these parameters based on detailed bank-level data available at the Deutsche Bundesbank for all foreign countries in which German banks operate. Before using the computed values to calibrate the model (see section 4), we compare the frictions that German banks face abroad across host countries. As one might expect, these are strongly related to proxies of bank entry barriers, such as financial openness or bureaucratic quality. We also check whether the modeled relationship between bank size and net interbank lending is supported by the data. In line with the theory, larger banks are more likely to be borrowers on the interbank market and borrow more on net than smaller banks.

\subsection{Structural equations}

For ease of notation, a bank is now denoted by subscript b. Subscript $j$, which is dropped where possible, stands for the bank's home country (Germany in our application). Country $i$ stands for the foreign country the (German) bank is lending to. $R_{i}-R^{I}$ is referred to as the net interest margin prevailing in country $i$, the interest collected on loans net of (interbank) funding costs.

Bank efficiency distribution With quadratic monitoring costs, a bank's domestic lending is given by $z_{b}=a_{b}\left(R_{j}-R^{I}\right)$. The efficiency of bank $b$ relative to bank $b^{\prime}$ is then equal to the ratio of the two banks' domestic loans to firms:

$$
\frac{a_{b^{\prime}}}{a_{b}}=\frac{z_{b^{\prime}}}{z_{b}}
$$

Denoting the bank with the largest domestic non-bank private sector lending by $\bar{b}$ and normalizing this bank's efficiency parameter so that $a_{\bar{b}}=\frac{z_{\bar{b}}}{R_{j}-R^{I}}$, where $R_{j}-R^{I}$ is proxied by the domestic net interest margin, we can obtain the efficiency parameter $a_{b}$ for each bank $b$.

Distribution of $\phi$ The model also prescribes a relationship between a bank's efficiency parameter $a_{b}$ and its cross-border lending and affiliate lending, respectively. Recall that $z_{b i}^{X}=$ $a_{b} \phi_{b i} \delta_{i}^{X}\left(R_{i}-R^{I}\right)$ and $z_{b i}^{F}=a_{b} \phi_{b i}\left(R_{i}-R^{I}\right)$, where $\phi_{b i}$ is bank $b$ 's idiosyncratic advantage of lending to country $i$. Dividing bank $b$ 's cross-border lending to firms in country $i$ by bank $b^{\prime}$ 's cross-border lending to firms in country $i$ and solving for the ratio $\frac{\phi_{b^{\prime} i}}{\phi_{b i}}$, we have:

$$
\frac{\phi_{b^{\prime} i}}{\phi_{b i}}=\frac{z_{b^{\prime} i}^{X}}{z_{b i}^{X}} \frac{a_{b}}{a_{b}^{\prime}} .
$$

Equivalently:

$$
\frac{\phi_{b^{\prime} i}}{\phi_{b i}}=\frac{z_{b^{\prime} i}^{F}}{z_{b i}^{F}} \frac{a_{b}}{a_{b}^{\prime}} .
$$


Exploiting $E\left(\phi_{b i}\right)=1$ to normalize $\phi_{b i}$, that is, setting $\sum_{b} \phi_{b i}=1$, we obtain for each bank $b$ that lends to country $i$ a value for $\phi_{b i} \cdot{ }^{17}$

Solving for $\delta^{X}$ and $\delta^{F}$ The model implies the following ratio of bank $b$ 's cross-border loans in country $i$ to its domestic loans:

$$
\frac{z_{b i}^{X}}{z_{b}}=\frac{a_{b} \phi_{b i} \delta_{i}^{X}\left(R_{i}-R^{I}\right)}{a_{b}\left(R_{j}-R^{I}\right)} .
$$

Solving for $\delta_{i}^{X}$ yields:

$$
\delta_{i}^{X}=\frac{z_{b i}^{X}}{z_{b}} \frac{\left(R_{j}-R^{I}\right)}{\left(R_{i}-R^{I}\right) \phi_{b i}} .
$$

Having determined $\phi_{b i}$, we can calculate $\delta_{i}^{X}$ for each country $i$ using information on cross-border loans $z_{b i}^{X}$ and domestic loans $z_{b}$ from the data.

Equivalently, $\delta_{i}^{F}$ can be obtained through:

$$
\delta_{i}^{F}=\frac{z_{b i}^{F}}{z_{b}} \frac{\left(R_{j}-R^{I}\right)}{\left(R_{i}-R^{I}\right) \phi_{b i}} .
$$

Solving for $f^{X}$ and $f^{F}$ The model solution for the cross-border lending cutoff $\tilde{a}_{i}^{X}$, that is, the efficiency of the bank that breaks even on its cross-border lending to country $i$ is:

$$
\tilde{a}_{i}^{X}=\frac{2 f_{i}^{X}}{\left(R_{i}-R^{I}\right)^{2} \delta_{i}^{X}} .
$$

Solving for the fixed cost $f_{i}^{X}$ delivers:

$$
f_{i}^{X}=\frac{1}{2} \tilde{a}_{i}^{X}\left(R_{i}-R^{I}\right)^{2} \delta_{i}^{X}
$$

With information on the net interest margin prevailing in country $i$ and the cutoff banker $\tilde{a}_{i}^{X}$ from the bank-level data, $f_{i}^{X}$ can be obtained by applying the above formula.

Similarly, the model provides an expression for the FDI cutoff $\tilde{a}_{i}^{F}$, i.e. the efficiency of the banker who is indifferent between lending cross-border or through an affiliate to market $i$ :

$$
\tilde{a}_{i}^{F}=\frac{2}{\left(R_{i}-R^{I}\right)^{2}} \frac{1}{\delta_{i}^{F}-\delta_{i}^{X}}\left(f_{i}^{F}-f_{i}^{X}-R^{I} d_{i}\right) .
$$

Solving for $f_{i}^{F}-R^{I} d_{i}$ delivers:

$$
f_{i}^{F}-R^{I} d_{i}=\frac{1}{2} \tilde{a}_{i}^{F}\left(R_{i}-R^{I}\right)^{2}\left(\delta_{i}^{F}-\delta_{i}^{X}\right)+f_{i}^{X}
$$

All the elements on the right hand side of the above expression are known from the data. So we can compute $f_{i}^{F}-R^{I} d_{b i}$, the fixed cost of establishing a foreign affiliate net of the benefit

\footnotetext{
${ }^{17}$ Note that $\phi_{b i}$ is normalized separately for banks with cross-border lending and banks with affiliate lending.
} 
from raising foreign deposits, for each country $i$.

\subsection{Data}

To implement the described strategy, we draw on balance sheets and foreign positions reports which German banks file with the Deutsche Bundesbank. These statistics are unique in that they provide extremely detailed information on German banks' domestic and foreign activities. In particular, one can observe each bank's cross-border assets and liabilities as well as the positions of its foreign subsidiaries and branches by sector and country. Available to us for this paper is monthly information for 2005, which we average over 12 months. ${ }^{18}$ The sample includes roughly 2,000 German banks, covering essentially the entire German banking sector except a few foreign-owned banks. Almost all of the banks in our sample have some non-zero foreign position but only around 50 have affiliates abroad. German banks conduct operations in around 180 foreign countries.

In addition to German bank-level data, we also use information on net interest margins across host countries from the World Bank's Financial Development and Structure Database (see Beck et al. (2000)). Summary statistics of all data used in the analysis are presented in table 1.

\subsection{Distribution of $a$ and $\phi$}

Calculating $a$ and $\phi$ The efficiency parameter $a_{b}$ for each German bank is calculated based on equation (20). $z_{b}$ is proxied by the loans of German bank $b$ to the domestic non-bank private sector. Figure 2 shows the distribution of $a_{b}$ obtained from the German data. Because the relationship between $a_{b}$ and $z_{b}$ is linear, the distribution reflects essentially the size distribution of German banks. The distribution resembles the Pareto distribution, a feature we exploit in the next section.

We also obtain $\phi_{b i}$ for each bank $b$ that lends to host country $i$. $\phi_{b i}$ reflects bank $b$ 's idiosyncratic advantage in lending to country $i$ and indirectly indicates how well the size of a bank's domestic lending predicts its foreign lending. In order to calculate $\phi_{b i}$, we divide German parent banks in three groups: ${ }^{19}$ (i) banks which do not have positions in country $i$, for which we cannot calculate $\phi_{b i}$ (domestic banks); (ii) banks which do not lend through foreign affiliates to country $i$ but which extend loans cross-border to country $i$ (cross-border banks). For these banks we obtain $\phi_{b i}$ by applying equation (21). (iii) Banks whose affiliates abroad lend to country $i$ (banks with FDI). In equation $(22), z_{b i}^{F}$ is proxied by the sum of total affiliate lending to country $i$, no matter whether the affiliate is located in country $i$ or in a third country, plus cross-border lending by the parent to country $i .^{20}$

\footnotetext{
${ }^{18}$ Research Data and Service Centre of the Deutsche Bundesbank, Monthly Balance Sheet Statistics and External Positions of Banks, 2005.

${ }^{19}$ The described grouping is based specifically on German banks' positions vis-à-vis the non-bank private sector in country $i$.

${ }^{20}$ For a discussion of the non-negligible role of German banks' third-country affiliates, see Frey and Kerl (2015).
} 
The relationship between domestic lending and foreign lending A bank's domestic lending volume is, in general, a strong predictor of its foreign lending. To illustrate this, we rank banks according to their cross-border loans to country $i$ and correlate this ranking with the ranking based on their lending to German firms $\left(a_{b}\right)$. The distribution of rank correlation coefficients across host countries is shown in figure 3 . The average rank correlation coefficient is 33 percent. Rank correlations are low or negative for countries that receive only few loans from German banks, for example, Guyana (correlation coefficient of -0.5) or Honduras (correlation coefficient of 0.1). For cross-border lending to firms in these countries, special knowledge about local markets or relationships may be highly relevant. Rank correlations are much higher for countries like Italy (correlation coefficient of 0.5) or the US (correlation coefficient of 0.6), which are key destinations for German banks' cross-border loans. Similar results emerge for banks' foreign lending via affiliates. The average rank correlation across host countries is slightly higher at 54 percent. $^{21}$

Figure 4 highlights the role played by $\phi_{b i}$ in the model, which captures the idiosyncratic advantage/disadvantage that bank $b$ faces when lending to country $i{ }^{22}$ Banks' cross-border lending to the non-bank private sector $z_{b i}^{X}$ is plotted against the efficiency parameter $a_{b}$ in the chart (scattered dots). If banks did not have any idiosyncratic advantage/disadvantage in lending to country $i, \phi_{b i}$ would be equal to 1 for each bank and all dots would lie on the straight line depicted in the chart. Applying the strategy described in the previous section, $\phi_{b i}$ is set for each bank to the value that makes the relationship between $\phi_{b i} a_{b}$ and $z_{b i}^{X}$ linear. The horizontal arrows in the chart reflect the adjustment through $\phi_{b i}$.

\subsection{Comparing $\delta^{X}, f^{X}, \delta^{F}$ and $f^{F}-R^{I} d$ across host countries}

Calculating $\delta^{X}, f^{X}, \delta^{F}$ and $f_{i}^{F}-R^{I} d$ The parameters $\delta_{i}^{X}$ and $\delta_{i}^{F}$ reflect inversely the efficiency loss that banks encounter when operating in country $i$ cross-border and through a foreign affiliate, respectively. The two parameters affect the intensive margin, that is, the volume of bank lending abroad. They are calculated based on equations (24) and (25).

To compute the fixed cost $f_{i}^{X}$ of cross-border lending and the fixed cost $f_{i}^{F}$ of establishing an affiliate in country $i$, we follow equations (27) and (29). For the calculation of the fixed costs, which affect the extensive margin of banks' foreign operations, we use a narrower definition to group banks into domestic, cross-border and FDI with respect to country $i$. Banks are only classified as having FDI if they have an affiliate in country $i .^{23}$ The cross-border lending cutoff $\tilde{a}_{i}^{X}$ corresponds to the lowest value of $\tilde{a}_{i}=\phi_{b i} a_{b}$ observed within the group of cross-border banks. Equivalently, the FDI cutoff $\tilde{a}_{i}^{F}$ is set to the lowest value of $\tilde{a}_{i}=\phi_{b i} a_{b}$ observed within the group of banks with FDI.

\footnotetext{
${ }^{21}$ These findings are consistent with Buch et al. (2011) and Niepmann (2013) who show that bank efficiency predicts the intensive margin (and extensive margin) of banks' foreign activities.

${ }^{22}$ We use artificially constructed data in this graph as original bank-level data cannot be shown due to confidentiality.

${ }^{23}$ The set of banks with local affiliate lending to country $i$ is smaller than the set of banks with local and/or affiliate lending channelled from third countries to country $i . \phi_{b i}$ is renormalized after banks are regrouped so that the mean of $\phi_{b i}$ within each group is 1 .
} 
Comparing $\delta^{X}, f^{X}, \delta^{F}$ and $f^{F}-R^{I} d$ across host countries The model puts some restrictions on the parameters $\delta_{i}^{X}, f_{i}^{X}, \delta_{i}^{F}$ and $f_{i}^{F}-R^{I} d_{i}$. For example, the model requires $\delta_{i}^{X}<\delta_{i}^{F} \leq 1 \forall i$. All values obtained for $\delta_{i}^{X}$ and $\delta_{i}^{F}$ are in fact below 1 and $\delta_{i}^{X}<\delta_{i}^{F}$ holds for all countries in our sample. Moreover, the fixed cost of cross-border lending $f_{i}^{X}$ is smaller than the fixed cost of establishing an affiliate net of the benefits from raising additional funding in market $i\left(f_{i}^{F}-R^{I} d_{i}\right)$, consistent with the model assumptions. Table 2 shows the computed values for $\delta^{X}, f^{X}, \delta^{F}$ and $f^{F}-R^{I} d$ for the different host countries in the sample. All values are expressed relative to the values obtained for the US for better illustration. Countries are sorted according to $\delta^{X}$.

Overall, German banks encounter relatively low frictions when lending to geographically close areas as well as European financial centers such as Luxembourg, Switzerland and Ireland. Beyond this general pattern, the efficiency loss from lending cross-border (inversely related to $\delta^{X}$ ) is small for the US compared to other countries, which is likely related to the country's large and competitive corporate loan market that is fairly open to foreign lenders. The fixed cost of establishing an affiliate is not only low in geographically close markets but also in more distant financial centers such as Hong Kong or Singapore. This fits well with these countries' policies to attract foreign banks, for example, through favorable tax conditions. The efficiency loss from lending via affiliates (inversely related to $\delta_{F}$ ) is particularly small in Central and Eastern European countries such as Bulgaria and Romania. This finding matches the fact that several German banks operate large subsidiaries in these markets which supply loans not only locally but also across borders to the whole region (see Frey and Kerl (2015)).

Regressing $\delta^{X}, f^{X}, \delta^{F}$ and $f^{F}-R^{I} d$ on host country characteristics To assess further whether the computed measures of the barriers to German banks' foreign operations are sensible, we conduct a simple cross-sectional regression analysis. We regress $\delta_{i}^{X}, f_{i}^{X}, \delta_{i}^{F}$ and $f_{i}^{F}-R^{I} d_{i}$ on several country characteristics. ${ }^{24}$ In particular, we include as explanatory variables host country GDP, distance to Germany and three proxies for bank entry barriers following Niepmann (2013): the Chinn and Ito index, which measure de jure financial openness (see Chinn (2008)), as well as measures of a country's bureaucratic quality and property rights protection from the World Bank. ${ }^{25}$ Controlling for GDP is essential since a country's size is a strong predictor of foreign bank activity (see, for example, Aviat and Coeurdacier (2007)) and differences in size across host markets are not automatically accounted for in the calculation of bank entry barriers. Summary statistics for all variables used in the empirical analysis are given in table 1. Regression results are presented in tables 3 and 4 . To get a better sense of how relevant the different variables are for predicting $\delta^{X}, f^{X}, \delta^{F}$ and $f^{F}-R^{I} d$, we calculate semipartial correlations between explanatory variables and dependent variables. Semipartial correlations measure the decrease in R-squared that results when the respective variable is omitted from the regression. They are presented in the bottom rows of tables 3 and 4 .

Overall, the efficiency loss from lending abroad and associated fixed costs tend to be lower

\footnotetext{
${ }^{24}$ The three highest and lowest values of each dependent variable are excluded from the sample. This essentially means excluding countries in which only very few German banks operate, that is, countries for which the calculated values of $\delta^{X}, f^{X}, \delta^{F}$ and $f^{F}-R^{I} d$ are based on only a few observations.

${ }^{25}$ See the data appendix for data sources and further details on the different variables.
} 
in countries with a better bureaucracy, better property rights protection and greater financial openness. The predictive power of these variables is particularly strong for the efficiency loss associated with cross-border and affiliate lending (inversely related to $\delta^{X}$ and $\delta^{F}$, respectively). Distance is linked to the efficiency loss from cross-border lending (see table 3, columns 1 to 3) but is not correlated with the efficiency loss from affiliate lending or the fixed cost of establishing an affiliate in country $i$ (see table 4). This indicates that local affiliates eliminate frictions that arise from distance. The fixed cost of cross-border lending and establishing an affiliate are significantly influenced by GDP, however, in opposite directions (see columns (4) to (6) in tables 3 and 4 ). While the fixed cost of cross-border lending $f^{X}$ is lower in countries with a bigger GDP, the fixed cost of FDI is higher. The positive effect of GDP on $f^{F}$ is somewhat surprising and may reflect tougher competition in bigger markets.

\subsection{Interbank lending in the model and the data}

The model yields predictions regarding each bank's interbank claims as a function of its efficiency. In the closed economy model and the open economy with interbank lending only, we have:

$$
z_{b}-d_{b}=a_{b}\left(R-R^{I}\right)-d_{b}
$$

where $d_{b}=d \forall b$. The equation implies that a bank's net interbank borrowing is an increasing function of its efficiency. This relationship stems from the assumption that each bank is endowed with the same amount of depositor capital but faces different monitoring costs. In the open economy model with cross-border and affiliate lending, the statement remains true under the sufficient condition that $z_{b i}^{F}-d_{b i} \geq 0$, in other words, the amount of additional deposits that banks with affiliates can raise abroad is not larger than the funds that these banks want to lend to non-banking firms abroad. ${ }^{26}$

Figure 5 plots the relationship of net interbank claims and bank efficiency $a_{b}$ in the German data obtained from a simple cross-sectional regression. Net interbank claims are computed as the difference between a bank's consolidated lending to foreign and domestic banks and its borrowing from these entities. Consistent with the model, there is a clear negative relationship between the two. Larger banks (higher $a_{b}$ ) are more likely to be net borrowers on the interbank market and borrow more on net than smaller banks. This finding is in line with descriptions of the structure of interbank markets in Stigum (1990) and Craig and von Peter (2014).

\section{The Composition of International Bank Flows}

In this section, we calibrate the model to the data and undertake a couterfactual analysis to study how the composition of international bank flows changes with impediments to foreign bank operations. We do not have data at hand that would allow us to sensibly simulate the N-country model, so we work in the following with a two-country version. Specifically, we use

\footnotetext{
${ }^{26}$ The sufficient condition guarantees that a bank's demand for interbank funds does not decline when it opens up an affiliate in a foreign country.
} 
the previously calculated parameters and detailed information on German bank positions in the US to simulate the model and bank flows between these two countries.

\subsection{Parameters used for simulation}

The parameter values used for the simulation are summarized in table 5. As figure 2 showed, the distribution of the efficiency parameter $a_{b}$ among German banks resembles the Pareto distribution. We assume a truncated Pareto distribution and estimate the shape parameter based on the computed $a_{b}$ 's for German banks with Maximum Likelihood. The upper limit of the truncated Pareto is set equal to the 99th percentile of the observed distribution of $a_{b} .{ }^{27}$ The bank efficiency distribution for the USA is assumed to have the same shape parameter and the same upper support as for German banks. ${ }^{28}$ The lower support of each country's bank efficiency distribution is chosen so that each country's net interest margin under autarky $\left(R_{i}-R^{I}\right)$ matches the 1998 value of the net interest margin, which is the earliest value available from Beck et al. (2000). ${ }^{29}$ This implies assuming that German banks are, on average, more efficient than US banks (average efficiency of $7.33 \mathrm{e}+07$ for German banks versus $1.58 \mathrm{e}+07$ for US banks).

The return on loans in Germany is set to $10 \%$. The return on loans in the US is determined by the difference in net interest margins between the US and Germany in 2005 from the Financial Structure Database, which implies $R_{U S A}=R_{G E R}+0.0252$.

$\tilde{a}_{b U S}=\phi_{b U S} a_{b}$ is also assumed to be Pareto distributed. The shape parameter of that distribution is estimated based on the computed values for $\tilde{a}_{b U S}$. The upper limit corresponds to the highest value of $\tilde{a}_{b U S}$ in the data. The lower limit of the distribution is not observed because $\phi_{b U S}$ can only be computed for banks that extend loans to US firms. We therefore choose the lower limit of the distribution so that the share of German banks that lend to US firms equals the empirical counterpart (61.85\%), where the cross-border cutoff $\tilde{a}_{b U S}^{X}$ is set equal to the lowest value of $\tilde{a}_{b U S}$ observed among banks with cross-border loans in the US.

The number (mass $M_{G E R}$ ) of German banks is taken from the German bank-level data and is 1,995. The number (mass $M_{U S}$ ) of US banks in the year 2005 comes from Janicki and Prescott (2006), which is 6,500. The capital endowment $K_{G E R}$ of German banks is set equal to the total deposits collected from German residents. US banks hold twice as many deposits as German banks, so we set $K_{U S}=2 \times K_{G E R} \cdot{ }^{30} \delta_{U S}^{X}, f_{U S}^{X}$, and $\delta_{U S}^{F}$ are based on the computations described in the previous section. The fixed cost $f^{F}$ of establishing an affiliate in the US is chosen so that German banks' total loans to the US non-bank private sector match those in

\footnotetext{
${ }^{27}$ We exploit the fact that when a Pareto distribution is truncted, the resulting distribution is also Pareto distributed and has the same shape parameter.

${ }^{28}$ Bremus et al. (2013) find similar Pareto shape parameters for Germany and the US.

${ }^{29}$ Ideally, we would like to go back further in time. However, the large rise in BIS foreign claims took place after 1998 as indicated by figure 1 so using 1998 values for autarky net interest margins seems sensible.

${ }^{30}$ See Board of Governors of the Federal Reserve Systems, http://www.federalreserve.gov/econresdata/releases/statisticsdata.htm, table H.8 - Assets and Liabilities of Commercial Banks in the U.S., and the Deutsche Bundesbank, Monthly Report, http://www.bundesbank.de/Navigation/EN/Publications/Monthly_reports/monthly_reports.html, table IV.2 Banks - Principal Assets and Liabilities of Banks (MFIs) in Germany, by Category of Banks.
} 
the data ( $€ 226 \mathrm{bn})$.

Because we do not have detailed data on US banks' positions in Germany, we assume that US banks lend to and borrow only from domestic firms and German banks but they do not lend to German non-banking firms or raise deposits in Germany. This implicitly means setting the entry costs for US banks prohibitively high. ${ }^{31}$

\subsection{Comparing the model to the data}

Column (3) of table 6 presents key characteristics of the simulated open economy. Column (5) of the same table shows the corresponding moments from the data. Overall, the model matches the data well. Recall that $f_{U S}^{F}$ was chosen so that German banks' total loans to the US non-bank private sector from the model and the data coincide. The share of banks that engage in cross-border lending in the model is $62.68 \%$ compared to $61.25 \%$ in the data. The share of banks with affiliates is lower than in the data $(0.026 \%$ in the model versus $0.6 \%$ in the data), while total local lending is higher ( $€ 223$ bn in the model versus $€ 199$ bn in the data). Net lending by German banks to US banks is negative both in the model and in the data so German banks are net borrowers from US banks on the international interbank market. The model generates net interbank lending of $€-77$ bn compared to $€-69$ bn in the data.

\subsection{Counterfactual analysis}

We are interested in studying how US openness to German bank operations affects the two economies. Based on the baseline simulation, we analyze the following three scenarios: (i) autarky, (ii) the case in which banks can only lend and borrow on the international interbank market and (iii), a reduction in the cost of establishing affiliates in the US faced by German banks of 10 percent compared to the baseline calibration. Columns (1), (2), and (4) of table 6 show model outcomes for these scenarios.

Autarky Under autarky, each banking sector only lends to domestic firms and intermediates domestic funds. The net interest margin in Germany and the US are $1.34 \%$ and 3.81\%, respectively, and correspond to the 1998 values in the Financial Structure Database. ${ }^{32}$ Net capital flows and interbank flows are zero.

International interbank market When interbank markets integrate, interbank rates equilibrate. Note that because banks can only lend to foreign banks but not to foreign firms directly, each additional unit invested in one of the two countries must be intermediated by domestic banks. While the return on loans is higher in the US than in Germany, US banks incur higher monitoring costs than German banks. Whether capital flows in equilibrium to Germany or the

\footnotetext{
${ }^{31}$ This is not an unreasonable assumption. According to the BIS statistics, the claims of German banks on the US non-bank private sector in 2005 were roughly 20 times higher than the claims of US banks on the German non-bank private sector.

${ }^{32}$ Note that the lower limits of the German and US bank efficiency distributions were set so that the model matches these values in autarky.
} 
US thus depends on the relative magnitudes of differences in the return on loans and differences in average bank efficiencies across countries. These are reflected implicitly in autarky interbank rates. The autarky interbank rate is higher in the US than in Germany (8.66\% versus 8.71\%), implying that the higher return on loans in the US outweighs the higher monitoring costs. In equilibrium, $€ 33.75$ bn flow through the interbank market from Germany to the US and the interbank rate equilibrates at $8.68 \%$. Accordingly, net interest margins in the two countries move in opposite directions. The net interest margin falls in Germany to $1.32 \%$ and rises in the US to $3.84 \%$.

Baseline calibration When the barriers to international bank operations are not prohibitively high and $\delta^{X}, \delta^{F}, f^{F}$ and $f^{X}$ take the calibrated values, the capital flow into the US rises to $€ 182.82$ bn. German banks find it profitable to replicate their business in the US and lend to US firms directly. This brings monitoring costs in the global economy down so that more capital can flow to the high return location. As German banks expand their balance sheets, their demand for interbank funds rises. As a result, the interbank lending rate increases and net interest margins fall in both countries to $1.21 \%$ and $3.73 \%$, respectively. The German banking sector expands in size, while the US banking sector, which does not operate abroad, contracts since German banks take over part of the intermediation business from US banks. Importantly, the direction of the net interbank flow reverses. To finance their lending to US firms, German banks take deposits in the US and, in addition, borrow $€ 76.85$ bn from US banks on the interbank market.

$\mathbf{1 0 \%}$ fall in $f^{F}$ Column (4) shows the implications of a 10 percent fall in the cost $f^{F}$ that German banks face when establishing an affiliate in the US. As the barriers to foreign bank entry go down, banks switch from cross-border lending to lending through local affiliates and increase their loan volumes to US firms. This, in turn, raises the demand for interbank funding so that the interbank lending rate rises further. The net interest margin falls to $1.1 \%$ in Germany and $3.62 \%$ in the US. With higher interbank lending rates, it is less profitable for German banks to lend cross-border to US firms so that the share of banks that engage in cross-border lending goes down to $62.04 \%$ and the volume of cross-border loans falls from $€ 42$ bn to $€ 39.8 \mathrm{bn}$. Overall total lending to US firms goes up to $€ 536 \mathrm{bn}$. Most of this increase is funded through the interbank market, leading to a total of $€ 188.27$ bn in net borrowing by German banks from US banks.

Comparing the composition of German banks' foreign lending, funding sources and gross capital flows The proposed model makes predictions regarding the composition of German bank loans in the US, the funding sources for these loans as well as the volume of capital flows as a function of frictions to foreign bank operations. The three charts in figure 6 further illustrate this. The top chart shows the composition of German banks' assets in the US when (i) only interbank lending is possible (bar on the left), (ii) in the baseline economy (bar in the middle), and (iii) in the scenario with a $10 \%$ lower fixed cost $f^{F}$ (bar on the right). While German bank loans in the US are entirely loans to US banks under scenario (i), they 
consist of loans to US non-banking firms by parent banks and local affiliates in the other two scenarios. This highlights that lending to non-banking firms and interbank lending can be seen as substitutes. As German banks are able to lend directly to US firms, they switch away from lending to US banks. ${ }^{33}$ A reduction in the barriers to establishing affiliates in the US increases local lending (by affiliates) while cross-border lending (by the parent) falls.

The next chart shows how German banks' assets in the US are funded. In the scenario with interbank lending only, lending to US banks is funded entirely through German deposits. In the baseline economy, in contrast, funding comes from US depositors, German depositors as well as US banks. Interbank funding and funding through US deposits becomes more important relative to German depositor funding as the barriers to foreign bank entry decline. ${ }^{34}$

The bottom chart illustrates the composition of bank flows between Germany and the US. With interbank lending only, all capital that flows between the US and Germany goes through the interbank market. In the baseline economy, there are more types of cross-border bank flows and total flows are higher. Under the assumption that US affiliates of German banks use US deposits to fund local lending, this type of lending and borrowing does not create cross-border bank flows. However, German banks extend loans to US non-banking firms cross-border. At the same time, parent banks partly fund the operations of their local affiliates, which leads to so called intrabank flows between German banks and their US affiliates. ${ }^{35}$ As the costs of establishing affiliates in the US fall, cross-border lending flows go down, while the volumes of net intrabank and interbank flows increase. ${ }^{36}$

The effect of changes in the return on loans As a final exercise, we study a 25 basis point reduction in the return on loans in Germany across scenarios. Table 7 shows the effects. In all three scenarios, capital is reallocated from German to US firms, although to varying degrees. The effect on net interbank lending does not go in the same direction. In scenario (i), in which banks only borrow and lend on the international interbank market, a lower return on loans in Germany leads to higher net interbank flows from German banks to US banks. This is because an expansion in credit in the US can only be achieved through domestic banks, who consequently borrow from German banks. In scenarios (ii) and (iii) in contrast, the lower return on loans in Germany causes an increase in interbank borrowing by German banks. Because these are more efficient and can lend directly to US firms, they expand their business in the US and borrow more from US banks.

\footnotetext{
${ }^{33}$ Similar to figure 1, the share of German claims on US banks relative to total German claims in the US has fallen steadily since the late 1990s. The difference between German claims on US banks and US claims on German banks in the BIS data (a proxy for net interbank lending between Germany and the US) became smaller over the period from 1999 to 2010, with the difference turning negative for the first time at the end of 2004. Based on the model, these patterns are consistent with a reduction of the barriers to German bank operations in the US.

${ }^{34}$ The model does not quantitatively match well the amount of US deposits that German banks take because competition for deposits is not modeled in great detail. However, the model is useful for its qualitative implications regarding bank liabilities and funding composition.

${ }^{35}$ In the chart, it is assumed that the affiliates of German banks do not raise funding on the interbank market from US banks but that the funds to fill the gap between affiliate loans and deposits are provided by the parent.

${ }^{36}$ Note that while the model pins down gross cross-border loans and gross local loans to US non-banking firms, only net interbank and intrabank flows are determined.
} 


\subsection{Interbank lending and lending to firms as substitutes}

The model highlights that interbank lending and lending to non-banking firms abroad can be seen as substitutes. If the barriers to foreign bank entry are prohibitively high, all bank flows are channeled through the international interbank market. As soon as banks are able to lend directly to firms, they will do so; lending by local affiliates and intra-bank lending replaces interbank lending and the direction of net flows on the international interbank market might actually reverse. Lower barriers to bank entry also imply that banks can take deposits in foreign countries, which can reduce lending and borrowing on the interbank market.

The data supports the model view that interbank lending and lending to the private sector are substitutes. In table 8, host countries in the German data are grouped into three similarly large bins according to their openness to foreign bank entry (high, middle, low openness) based on the three proxies employed before: the Chinn-Ito-Index, bureaucratic quality and property rights protection. ${ }^{37}$ The table compares the mean value of claims on banks relative to claims on the non-bank private sector (computed separately for each bank per country) across groups of countries. It shows that German banks hold on average significantly fewer claims on banks relative to claims on the non-bank private sector in countries with high levels of openness compared to countries with low levels of openness consistent with the model. ${ }^{38}$

\section{Conclusions}

This paper proposes a parsimonious model of banking across borders to study the composition of international bank activities, which take the form of international interbank lending, cross-border lending to firms and lending through affiliates in foreign markets. The structural approach allows us to analyze both qualitatively and quantitatively how banks' foreign asset positions, their funding sources as well as inter- and intrabank flows change in response to altering cross-border banking frictions.

We emphasize two key implications presented in our analysis. First, different types of bank activities are interconnected and are often substitutes (for example, lending to non-banking firms and lending to banks). They thus have to be studied jointly and not in isolation. This is an insight that can be useful especially for future empirical work. ${ }^{39}$

Second, policies that affect cross-border frictions alter the composition of banks' foreign activities and, thereby, how much credit is supplied by whom and how it is funded. The model in this paper is static and is reduced to the minimal ingredients, but it alludes to key issues that should be studied in richer models in the future. As the literature has shown, different types of international bank flows respond differently to foreign and domestic shocks. For example,

\footnotetext{
${ }^{37}$ Bins do not contain exactly the same number of countries since we allocated all countries with the same level of openness to the same bin.

${ }^{38} \mathrm{~A}$ similar pattern is also observed in the BIS data. The share of claims on banks compared to claims on the non-bank private sector held by BIS reporting countries is higher in less developed countries.

${ }^{39}$ Empirical studies tend to compare the responses of different types of international bank flows to shocks without taking into account that these flows are determined simultaneously.
} 
interbank lending appears to be less stable than cross-border or affiliate lending. ${ }^{40}$ The model thus indicates that policies that affect entry barriers have consequences for domestic financial stability and ultimately, real economic activity. More research is needed to better understand banks' global business models and margins of adjustments to balance sheet shocks. At the same time, global banks' profit maximizing behavior and margins of adjustments should be integrated in international macro models to better understand the consequences of banking sector integration for financial stability and welfare. This paper delivers one building block to achieve this.

${ }^{40}$ For references, see footnotes 5 and 6 . 


\section{References}

Aviat, Antonin and Nicolas Coeurdacier, "The geography of trade in goods and asset holdings," Journal of International Economics, March 2007, 71 (1), 22-51.

Beck, Thorsten, Asli Demirguc-Kunt, and Ross Levine, "A New Database on the Structure and Development of the Financial Sector," World Bank Economic Review, 2000, $14(3), 597-605$.

Boissay, Frederic, "Financial imbalances and financial fragility," Working Paper Series 1317, European Central Bank 2011.

Bremus, Franziska, Claudia Buch, Katheryn Russ, and Monika Schnitzer, "Big Banks and Macroeconomic Outcomes: Theory and Cross-Country Evidence of Granularity," NBER Working Papers 19093, National Bureau of Economic Research, Inc May 2013.

Bruno, Valentina and Hyun Song Shin, "Cross-Border Banking and Global Liquidity," Review of Economic Studies, 2015, 82 (2), 535-564.

Buch, Claudia M., "Information or Regulation: What Drives the International Activities of Commercial Banks," Journal of Money, Credit and Banking, 2003, 35 (6), 851-869.

_, Catherine Tahmee Koch, and Michael Koetter, "Size, productivity and international banking," Journal of International Economics, 2011, 85 (2), 329-334.

Cetorelli, Nicola and Linda S. Goldberg, "Global Banks and International Shock Transmission: Evidence from the Crisis," IMF Economic Review, 2011, 59 (1), 41-76.

Chinn, Menzie, "A New Measure of Financial Openness," Journal of Comparative Policy Analysis, 2008, 10.

Chodorow-Reich, Gabriel, "The Employment Effects of Credit Market Disruptions: Firmlevel Evidence from the 2008-09 Financial Crisis," The Quarterly Journal of Economics, 2014, 129 (1), 1-59.

Cihak, Martin, Aslı Demirgüç-Kunt, Erik Feyen, and Ross Levine, "Benchmarking financial development around the world," World Bank Policy Research Working Paper, 2012, $6175,1-58$.

Corbae, Dean and Pablo D'Erasmo, "A Quantitative Model of Banking Industry Dynamics," 2010 Meeting Papers 268, Society for Economic Dynamics 2010.

_ and _ , "Capital requirements in a quantitative model of banking industry dynamics," Working Papers 14-13, Federal Reserve Bank of Philadelphia 2014.

Craig, Ben R. and Goetz von Peter, "Interbank tiering and money center banks," Journal of Financial Intermediation, 2014, 23 (3), 322-347. 
de Blas, Beatriz and Katheryn Niles Russ, "FDI in the Banking Sector," NBER Working Papers 16029, National Bureau of Economic Research 2010.

_ and _ , "All banks great, small, and global: Loan pricing and foreign competition," International Review of Economics \&5 Finance, 2013, 26 (C), 4-24.

de Haas, Ralph and Iman van Lelyveld, "Foreign banks and credit stability in Central and Eastern Europe. A panel data analysis," Journal of Banking E Finance, July 2006, 30 (7), 1927-1952.

_ and _ , "Internal capital markets and lending by multinational bank subsidiaries," Journal of Financial Intermediation, January 2010, 19 (1), 1-25.

_ and _, "Multinational Banks and the Global Financial Crisis: Weathering the Perfect Storm?," Journal of Money, Credit and Banking, 02 2014, 46 (s1), 333-364.

_ and Neeltje van Horen, "Running for the Exit? International Bank Lending During a Financial Crisis," Review of Financial Studies, 2013, 26 (1), 244-285.

de Sousa, Jose, Thierry Mayer, and Soledad Zignago, "Market access in global and regional trade," Regional Science and Urban Economics, 2012, 42 (6), 1037-1052.

Degryse, Hans and Steven Ongena, "Distance, Lending Relationships, and Competition," The Journal of Finance, 2005, 60 (1), 231-266.

Duewel, Cornelia, Rainer Frey, and Alexander Lipponer, "Cross-border bank lending, risk aversion and the financial crisis," Discussion Paper Series 1: Economic Studies 2011,29, Deutsche Bundesbank, Research Centre 2011.

Focarelli, Dario and Alberto Franco Pozzolo, "Where Do Banks Expand Abroad? An Empirical Analysis," Journal of Business, November 2005, 78 (6), 2435-2464.

Frey, Rainer and Cornelia Kerl, "Multinational banks in the crisis: Foreign affiliate lending as a mirror of funding pressure and competition on the internal capital market," Journal of Banking \& Finance, 2015, 50, 52-68.

Greenwood, Jeremy, Juan M. Sanchez, and Cheng Wang, "Quantifying the impact of financial development on economic development," Review of Economic Dynamics, 2013, 16 (1), 194 - 215. Special issue: Misallocation and Productivity.

Head, Keith, Thierry Mayer, and John Ries, "The erosion of colonial trade linkages after independence," Journal of International Economics, May 2010, 81 (1), 1-14.

Janicki, Hubert and Edward Prescott, "Changes in the size distribution of U.S. banks: 1960-2005," Economic Quarterly, 2006, (Fall), 291-316.

Jeon, Bang Nam, Maria Pia Olivero, and Ji Wu, "Multinational banking and the international transmission of financial shocks: Evidence from foreign bank subsidiaries," Journal of Banking \& Finance, 2013, 37 (3), 952-972. 
Kamil, Herman and Kulwant Rai, "The Global Credit Crunch and Foreign Banks' Lending to Emerging Markets: Why Did Latin America Fare Better?," IMF Working Papers 10/102, International Monetary Fund April 2010.

Khwaja, Asim Ijaz and Atif Rehman Mian, "Tracing the Impact of Bank Liquidity Shocks: Evidence from an Emerging Market," American Economic Review, 2008, 98 (4), 1413-42.

Kollmann, Robert, "Global Banks, Financial Shocks, and International Business Cycles: Evidence from an Estimated Model," Journal of Money, Credit and Banking, 2013, 45 (s2), 159-195.

_, Zeno Enders, and Gernot J. Mueller, "Global banking and international business cycles," European Economic Review, 2011, 55 (3), 407 - 426. Special Issue: Advances in International Macroeconomics: Lessons from the Crisis.

McCauley, Robert, Patrick McGuire, and Goetz von Peter, "After the global financial crisis: From international to multinational banking?" Journal of Economics and Business, 2012, 64 (1), $7-23$.

Milesi-Ferretti, Gian-Maria and Cedric Tille, "The great retrenchment: international capital flows during the global financial crisis," Economic Policy, 04 2011, 26 (66), 289-346.

Niepmann, Friederike, "Banking across borders with heterogeneous banks," Staff Reports 609, Federal Reserve Bank of New York 2013.

_ , "Banking across borders," Journal of International Economics, 2015, 96 (2), 244 - 265.

Olivero, Maria Pia, "Market power in banking, countercyclical margins and the international transmission of business cycles," Journal of International Economics, March 2010, 80 (2), 292-301.

Ongena, Steven, Jose Luis Peydro, and Neeltje van Horen, "Shocks Abroad, Pain at Home? Bank-Firm Level Evidence on the International Transmission of Financial Shocks," DNB Working Papers 385, Netherlands Central Bank, Research Department July 2013.

Popov, Alexander and Gregory F. Udell, "Cross-border banking, credit access, and the financial crisis," Journal of International Economics, 2012, 87 (1), 147-161.

Reinhardt, Dennis and Steven J. Riddiough, "The two faces of cross-border banking flows: an investigation into the links between global risk, arms-length funding and internal capital markets," Working Paper 498, Bank of England April 2014.

Rosengren, Eric S. and Joe Peek, "Collateral Damage: Effects of the Japanese Bank Crisis on Real Activity in the United States," American Economic Review, March 2000, 90 (1), 30-45. 
Schnabl, Philipp, "The International Transmission of Bank Liquidity Shocks: Evidence from an Emerging Market," The Journal of Finance, 2012, 67 (3), 897-932.

Stigum, Marcia, The Money Market, Dow Jones-Irwin, Homewood, IL, 1990. 


\section{A Data Appendix}

Data from the Deutsche Bundesbank: The main data source for the empirical analysis in this paper are the External Positions Reports and Balance Sheet Statistics that German banks file with the Deutsche Bundesbank on a monthly basis. These reports contain information the positions of parent banks, their branches and subsidiaries by country and sector. Banklevel data is confidential but available for research purposes on the premises of the Deutsche Bundesbank. All data used in this paper is for 2005. Our sample excludes foreign owned banks but comprises all domestically-owned banks with a German banking license. Banks fall into one of the following categories: commercial banks, Landesbanken, savings banks, regional institutions of credit cooperatives, credit cooperatives, building credit societies, savings and loan associations, and banks with special functions. We work with claims on the foreign nonbank private sector and claims on the foreign banking sector, excluding claims on foreign central banks. Claims represent accounts receivable and do not include securities holdings. When consolidating the parent bank and its affiliates, intragroup exposures are netted out by declaring liabilities that affiliates have on the German banking sector as representing parent bank funding.

Net interest margins: Information on net interest margins by country for 1998 and 2005 is from the World Bank's Financial Development and Structure Dataset. Descriptions of this dataset can be found in Beck et al. (2000) and Cihak et al. (2012). The net interest margin for the Netherlands Antilles is proxied by the value for Curaçao. The net interest margin for Serbia and Montenegro is the average between the net interest margins of the two countries.

Chinn-Ito openness index: Capital account openness is proxied by the Chinn \& Ito Index documented in Chinn (2008). It is a de jure measure of openness, which increases with greater capital account openness of a country.

Bureaucratic quality: Bureaucratic quality is from the International Country Risk Guide provided by the PRS Group. ${ }^{41}$ A high value of the index means that obstacles to conduct business stemming from bureaucracy are low, as bureaucracy "has the strength and expertise to govern without drastic changes in policy or interruptions in government services".

Property rights protection: Information on property rights protection comes from the Heritage Foundation. ${ }^{42}$ The index increases with greater protection of private property by a country's laws and the enforcement of those laws.

Other country-level variables: GDP in current U.S. dollars is from the World Development Indicators. Distance from Germany to foreign countries comes from a dataset provided by CEPII (see de Sousa et al. (2012) and Head et al. (2010)).

\footnotetext{
${ }^{41}$ See http://www.prsgroup.com/about-us/our-two-methodologies/icrg

${ }^{42}$ See http://www.heritage.org/index/property-rights.
} 


\section{B Proof of Proposition 1}

Proof. When $R^{I}=\max \left\{R_{1}, R_{2}, \ldots, R_{N}\right\}$, RHS of equation 17 is equal to zero. If $R^{I}=0$, then $R H S>\sum_{i=1}^{N} K_{i}$ because monitoring is assumed to be beneficial, which implies $K_{i} a_{i}^{\prime} R_{i}>K_{i}$. RHS of equation 17 is strictly decreasing in $R^{I}$ on the interval $R^{I} \in\left[0, \max \left\{R_{1}, R_{2}, \ldots, R_{N}\right\}\right]$. To see this, note that:

$$
\begin{aligned}
& \frac{\partial R H S}{\partial R^{I}}=M_{i} \int_{\underline{a}_{i}}^{\bar{a}_{i}} \frac{\partial z_{i i}}{\partial R^{I}} g_{i}\left(a_{i}\right) d a_{i}+ \\
& +\sum_{j=1, j \neq i}^{N} M_{j}\left(\int_{\tilde{a}_{i j}^{X}}^{\tilde{a}_{i j}^{F}} \frac{\partial z_{i j}^{X}}{\partial R^{I}} n_{i j}\left(\tilde{a}_{i j}\right) d \tilde{a}_{i j}+\frac{\partial \tilde{a}_{i j}^{F}}{\partial R^{I}} z_{i j}^{X}\left(\tilde{a}_{i j}^{F}\right)-\frac{\partial \tilde{a}_{i j}^{X}}{\partial R^{I}} z^{X}\left(\tilde{a}_{i j}^{X}\right)\right) \\
& +\sum_{j=1, j \neq i}^{N} M_{j}\left(\int_{\tilde{a}_{i j}^{F}}^{\overline{\tilde{a}}_{i j}} \frac{\partial z_{i j}^{F}}{\partial R^{I}} n_{i j}\left(\tilde{a}_{i j}\right) d \tilde{a}_{i j}-\frac{\partial \tilde{a}_{i j}^{F}}{\partial R^{I}} z^{F}\left(\tilde{a}_{i j}^{F}\right)\right) \\
& =\underbrace{M_{i} \int_{\underline{a}_{i}}^{\bar{a}_{i}} \frac{\partial z_{i i}}{\partial R^{I}} g_{i}\left(a_{i}\right) d a_{i}}_{<0}+\underbrace{\sum_{j=1, j \neq i}^{N} M_{j}\left(\int_{\tilde{a}_{i j}^{X}}^{\tilde{a}_{i j}^{F}} \frac{\partial z_{i j}^{X}}{\partial R^{I}} n_{i j}\left(\tilde{a}_{i j}\right) d \tilde{a}_{i j}+\int_{\tilde{a}_{i j}^{F}}^{\overline{\tilde{a}}_{i j}} \frac{\partial z_{i j}^{F}}{\partial R^{I}} n_{i j}\left(\tilde{a}_{i j}\right) d \tilde{a}_{i j}\right)}_{\leq 0}+ \\
& +\sum_{j=1, j \neq i}^{N} M_{j}\left(\frac{\partial \tilde{a}_{i j}^{F}}{\partial R^{I}}\left(z^{X}\left(\tilde{a}_{i j}^{F}\right)-z^{F}\left(\tilde{a}_{i j}^{F}\right)\right)\right)-\underbrace{\frac{\partial \tilde{a}_{i j}^{X}}{\partial R^{I}} z^{X}\left(\tilde{a}_{i j}^{X}\right)}_{\geq 0} .
\end{aligned}
$$

$z_{i j}^{X}\left(\tilde{a}_{i j}\right)<z_{i j}^{F}\left(\tilde{a}_{i j}\right)$ because $\delta_{i j}^{X}<\delta_{i j}^{F} \Rightarrow z_{i j}^{X}\left(\tilde{a}_{i j}^{F}\right)-z_{i j}^{F}\left(\tilde{a}_{i j}^{F}\right)<0$. Under the assumption that $f_{i j}^{F}>f_{i j}^{X}-\frac{K_{i}}{M_{i}} \max \left\{R_{1}, R_{2}, \ldots, R_{N}\right\}, \frac{\partial \tilde{a}_{i j}^{F}}{\partial R^{I}} \geq 0$. This implies that $\frac{\partial R H S}{\partial R^{I}}<0$. With RHS of equation 17 being strictly decreasing in $R^{I}$, it follows that RHS of equation 17 cuts LHS of equation 17 once from above on the intervale $\left.\left.R^{I} \in\right] 0, \max \left\{R_{1}, R_{2}, \ldots, R_{N}\right\}\right]$. 

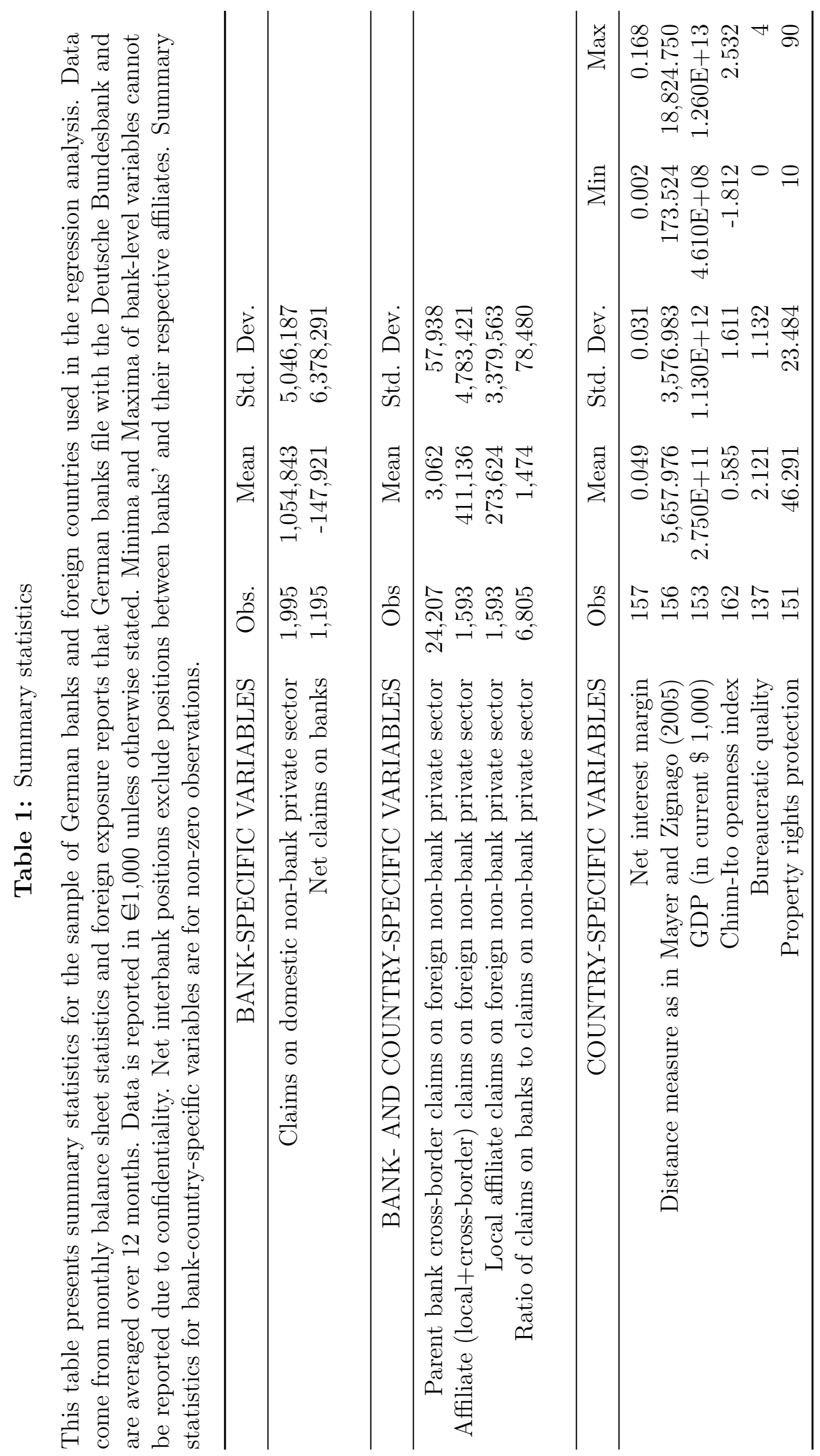


\section{Table 2: German banks' frictions of operating abroad by country}

This table reports the values of $\delta_{i}^{X}, \delta_{i}^{F}, f_{i}^{X}$ and $f_{i}^{F}-R^{I} d_{i}$ for various host countries $i$ obtained from applying the strategy described in section 3 to bank-level data from the Deutsche Bundesbank for the year 2005. For better illustration, all parameter values were divided by the respective values for the United States. $\delta_{i}^{X}\left[\delta_{i}^{F}\right]$ is an inverse measure of the efficiency loss that a banker incurs when lending cross-border [through a local affiliate] to firms in country $i . f_{i}^{X}$ represents the fixed cost of cross-border lending; $f_{i}^{F}-R^{I} d_{i}$ stands for the fixed cost of establishing an affiliate net of the benefits from raising deposits in country $i$. Not all values that were computed can be shown due to confidentiality.

\begin{tabular}{|c|c|c|c|c|c|c|c|c|c|}
\hline Country & $\delta^{X}$ & $f^{X}$ & $\delta^{F}$ & $f^{F}-R^{I} d$ & Country $i$ & $\delta^{X}$ & $f^{X}$ & $\delta^{F}$ & $f^{F}-R^{I} d$ \\
\hline Luxembourg & 4.02602 & 0.350 & 0.3321 & 0.00011 & Korea, Rep. & 0.01979 & 1.188 & 0.0060 & \\
\hline Netherlands & 3.13475 & 0.117 & 0.4332 & 0.00895 & Mauritius & 0.01794 & 1.745 & 0.0015 & \\
\hline Poland & 2.57348 & 2.498 & 0.0288 & 0.00128 & Ukraine & 0.01713 & 2.395 & 0.0012 & \\
\hline France & 2.33543 & 0.442 & 0.3230 & 0.00162 & Namibia & 0.01652 & 4.374 & & \\
\hline Uruguay & 2.26136 & 2.287 & & & Cameroon & 0.01608 & 24.948 & & \\
\hline Switzerland & 1.61588 & 0.388 & 0.3097 & 0.00007 & Brunei Darussalam & 0.01532 & 12.082 & & \\
\hline Denmark & 1.56711 & 0.810 & 0.0336 & & Aruba & 0.01497 & 3.431 & & \\
\hline Norway & 1.26851 & 0.858 & & & Colombia & 0.01489 & 1.952 & & \\
\hline United States & 1 & 1 & 1 & 1 & Morocco & 0.01327 & 2.318 & & \\
\hline Austria & 0.87210 & 0.885 & 0.1263 & 0.00033 & Mali & 0.01294 & 3.677 & & \\
\hline Belgium & 0.73548 & 0.481 & 0.1141 & 0.00048 & Brazil & 0.01235 & 3.318 & 0.0054 & 0.01251 \\
\hline Malta & 0.70782 & 1.614 & & & Tanzania & 0.01184 & 4.776 & & \\
\hline Belize & 0.49601 & 4228.198 & & & Indonesia & 0.01148 & 3.075 & 0.0049 & \\
\hline Cyprus & 0.46795 & 0.537 & & & Jamaica & 0.01147 & 4.974 & & \\
\hline Panama & 0.46341 & 1.136 & 0.3888 & & United Arab Emirates & 0.01129 & 1.408 & 0.0136 & \\
\hline Sweden & 0.38843 & 0.448 & 0.0610 & & Sri Lanka & 0.01073 & 3.058 & 0.0005 & \\
\hline India & 0.32409 & 2.237 & 0.0305 & & Mongolia & 0.01013 & 11.670 & & \\
\hline Japan & 0.28145 & 0.686 & 0.4200 & 0.00685 & Pakistan & 0.01007 & 3.037 & 0.0009 & \\
\hline Iceland & 0.27593 & 0.099 & & & Benin & 0.00996 & 0.161 & & \\
\hline Spain & 0.27519 & 1.227 & 0.0879 & 0.04086 & Djibouti & 0.00965 & 3.318 & & \\
\hline Canada & 0.25783 & 0.905 & 0.0470 & & Philippines & 0.00929 & 3.112 & 0.0026 & \\
\hline Czech Republic & 0.19853 & 1.603 & 0.0186 & 0.00036 & Ecuador & 0.00892 & 3.774 & & \\
\hline Greece & 0.19764 & 2.605 & 0.0182 & 0.01046 & El Salvador & 0.00882 & 3.831 & & \\
\hline Cuba & 0.18892 & 0.989 & & & Guatemala & 0.00857 & 3.102 & & \\
\hline Slovenia & 0.14518 & 1.708 & & & Serbia and Montenegrob & 0.00825 & 4.064 & 0.0010 & \\
\hline Lebanon & 0.14262 & 1.760 & & & Romania & 0.00814 & 2.737 & 0.0032 & \\
\hline Macedonia, FYR & 0.14149 & 3.310 & & & Bolivia & 0.00800 & 3.081 & & \\
\hline Nicaragua & 0.14111 & 4.271 & & & Azerbaijan & 0.00785 & 3.281 & & \\
\hline Ireland & 0.13535 & 0.483 & 0.2083 & 0.00029 & Vietnam & 0.00705 & 1.402 & 0.0003 & \\
\hline Argentina & 0.13302 & 1.204 & 0.4370 & & Georgia & 0.00632 & 8.049 & & \\
\hline Saudi Arabia & 0.12559 & 2.303 & & & Paraguay & 0.00622 & 5.901 & & \\
\hline Myanmar & 0.12456 & 0.589 & & & Mozambique & 0.00587 & 4.411 & & \\
\hline Chile & 0.12099 & 2.621 & 0.3575 & & Burkina Faso & 0.00532 & 3.361 & & \\
\hline Hungary & 0.09467 & 2.895 & 0.0158 & 0.00853 & Uganda & 0.00522 & 8.344 & & \\
\hline Togo & 0.09246 & 1.433 & & & Malawi & 0.00518 & 7.940 & & \\
\hline Latvia & 0.09143 & 1.981 & 0.0105 & & Cote d'Ivoire & 0.00505 & 3.762 & & \\
\hline Algeria & 0.08428 & 2.582 & & & Libya & 0.00469 & 0.063 & & \\
\hline Turkey & 0.08181 & 0.577 & 0.0535 & & Dominican Republic & 0.00438 & 7.236 & & \\
\hline Russian Federation & 0.08166 & 2.285 & 0.0214 & 0.08666 & Uzbekistan & 0.00387 & 2.282 & & \\
\hline Finland & 0.07953 & 0.359 & 0.0577 & & Syrian Arab Republic & 0.00371 & 2.674 & & \\
\hline Egypt, Arab Rep. & 0.07877 & 1.074 & & & Kenya & 0.00366 & 6.820 & & \\
\hline China & 0.07633 & 1.256 & 0.0138 & 0.01059 & Yemen, Rep. & 0.00341 & 7.184 & & \\
\hline Italy & 0.06570 & 1.483 & 0.1033 & 0.14500 & Sudan & 0.00289 & 7.019 & & \\
\hline Australia & 0.06497 & 1.411 & 0.0557 & & Grenada & 0.00278 & 167.594 & & \\
\hline Kazakhstan & 0.06462 & 3.050 & & & Guinea & 0.00266 & 13.331 & & \\
\hline Neth. Antillesa & 0.06339 & 4.761 & 0.0148 & & Nepal & 0.00256 & 2.784 & & \\
\hline Qatar & 0.06290 & 1.516 & & & Lao PDR & 0.00248 & 2.021 & & \\
\hline Hong Kong SAR, China & 0.05817 & 1.406 & 0.0022 & 0.00003 & Oman & 0.00247 & 2.394 & & \\
\hline Estonia & 0.05286 & 0.880 & 0.0030 & & Mauritania & 0.00244 & 4.553 & & \\
\hline Malaysia & 0.05175 & 1.322 & 0.0044 & 0.00373 & Botswana & 0.00223 & 3.830 & & \\
\hline Thailand & 0.05121 & 1.944 & 0.0030 & & Trinidad and Tobago & 0.00191 & 3.228 & & \\
\hline Jordan & 0.05042 & 2.085 & & & Gambia, The & 0.00186 & 6.366 & & \\
\hline South Africa & 0.05030 & 1.768 & 0.0035 & & Lesotho & 0.00154 & 4.106 & & \\
\hline Slovak Republic & 0.04944 & 1.628 & 0.0032 & & Chad & 0.00117 & 4.715 & & \\
\hline Bulgaria & 0.04792 & 3.107 & 0.0020 & & Sierra Leone & 0.00116 & 9.079 & & \\
\hline Bosnia and Herzegovina & 0.04576 & 2.879 & 0.0007 & & Senegal & 0.00086 & 3.958 & & \\
\hline Tunisia & 0.04429 & 1.847 & & & Peru & 0.00076 & 3.309 & & \\
\hline Costa Rica & 0.04042 & 4.764 & & & Cambodia & 0.00062 & 3.019 & & \\
\hline Israel & 0.03929 & 0.623 & & & Iraq & 0.00055 & 6.416 & & \\
\hline Croatia & 0.03754 & 1.562 & 0.0054 & & Tajikistan & 0.00050 & 9.191 & & \\
\hline Nigeria & 0.03703 & 3.535 & & & Niger & 0.00046 & 8.089 & & \\
\hline New Zealand & 0.03577 & 1.041 & 0.0285 & & Madagascar & 0.00042 & 5.662 & & \\
\hline Singapore & 0.03559 & 1.353 & 0.0600 & 0.00760 & Afghanistan & 0.00034 & 6.154 & & \\
\hline Venezuela, RB & 0.03397 & 4.731 & & & Haiti & 0.00026 & 14.466 & & \\
\hline Lithuania & 0.03294 & 2.415 & 0.0208 & & Moldova & 0.00025 & 8.120 & & \\
\hline Bahrain & 0.03141 & 1.045 & & & Central African Republic & 0.00020 & 5.748 & & \\
\hline Bangladesh & 0.02892 & 3.449 & & & Kyrgyz Republic & 0.00018 & 3.610 & & \\
\hline Belarus & 0.02728 & 1.427 & & & Rwanda & 0.00009 & 70.442 & & \\
\hline Kuwait & 0.02527 & 0.374 & & & Guyana & 0.00007 & 5.781 & & \\
\hline Honduras & 0.02348 & 9.790 & & & Swaziland & 0.00006 & 4.123 & & \\
\hline Ghana & 0.02335 & 10.873 & & & Burundi & 0.00003 & 13.557 & & \\
\hline Portugal & 0.02036 & 1.457 & 0.0301 & 0.00319 & & & & & \\
\hline
\end{tabular}




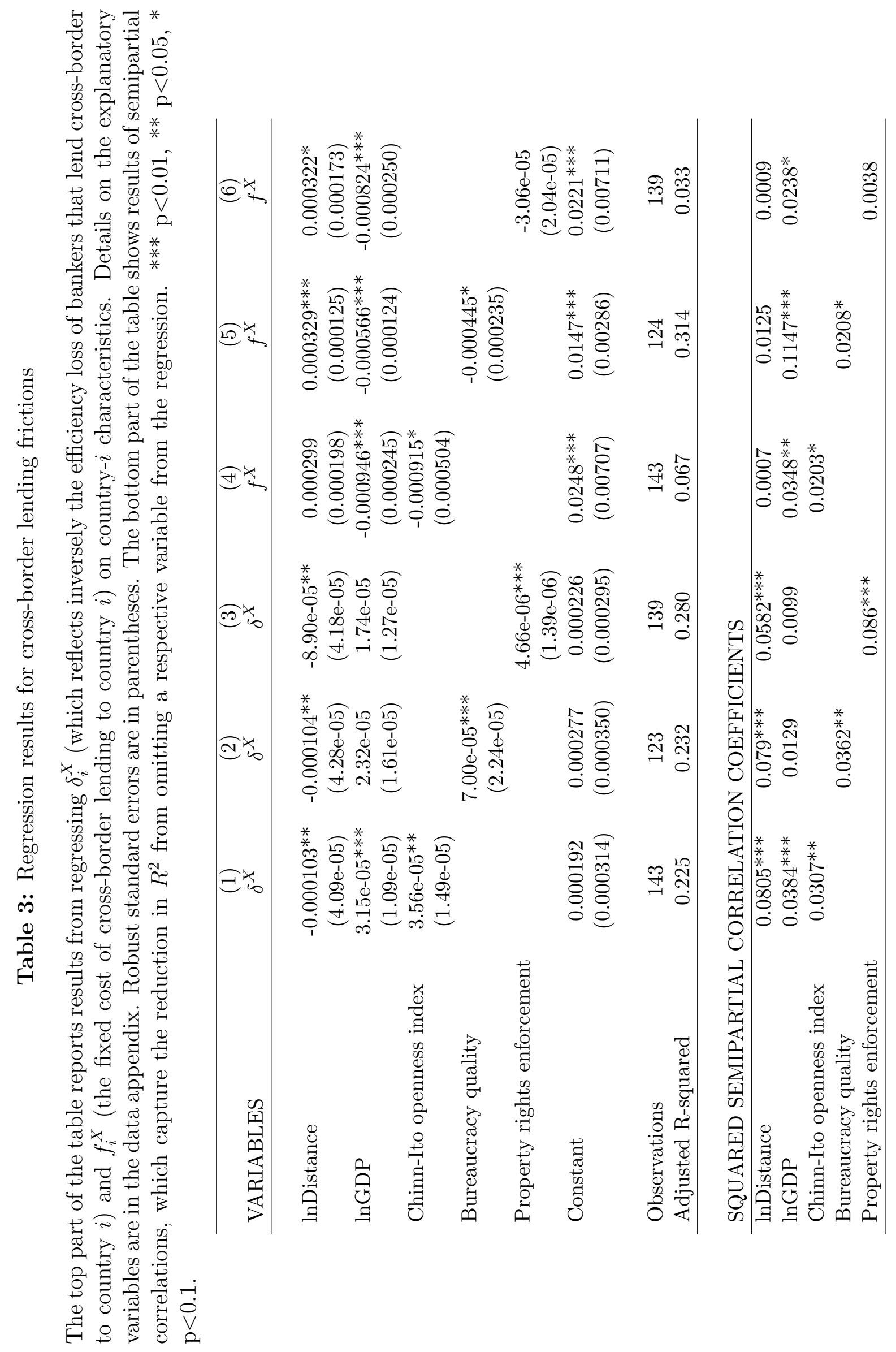




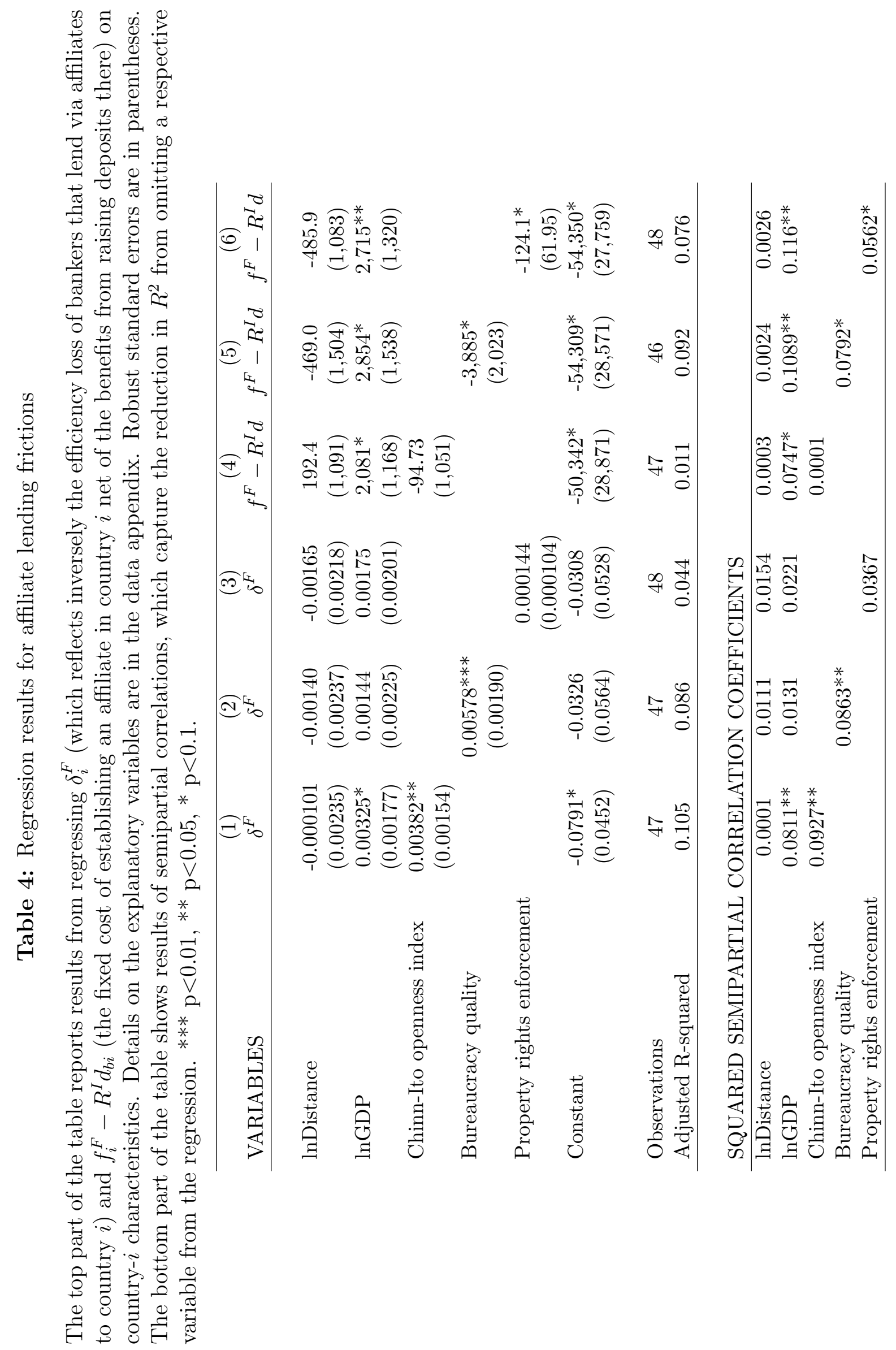




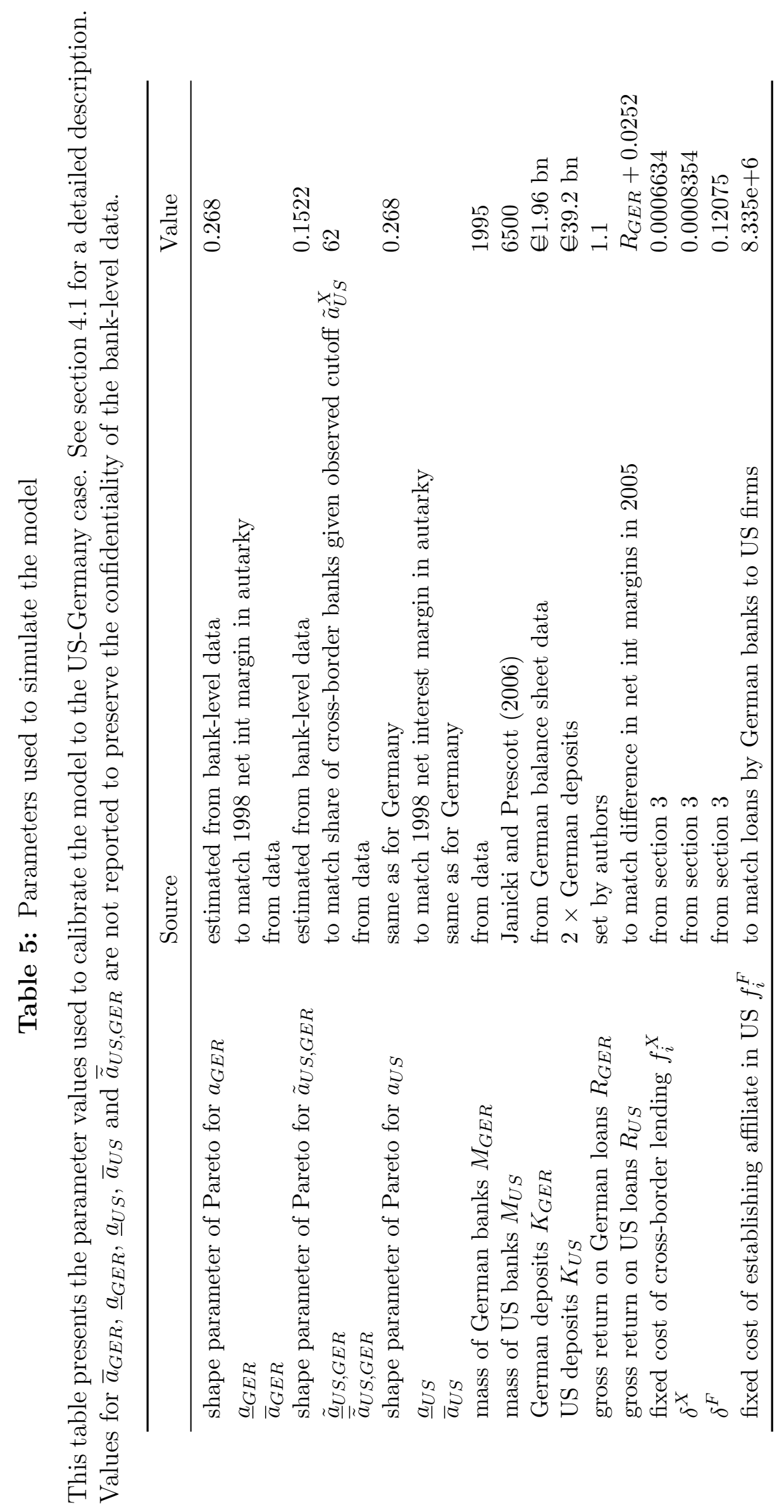




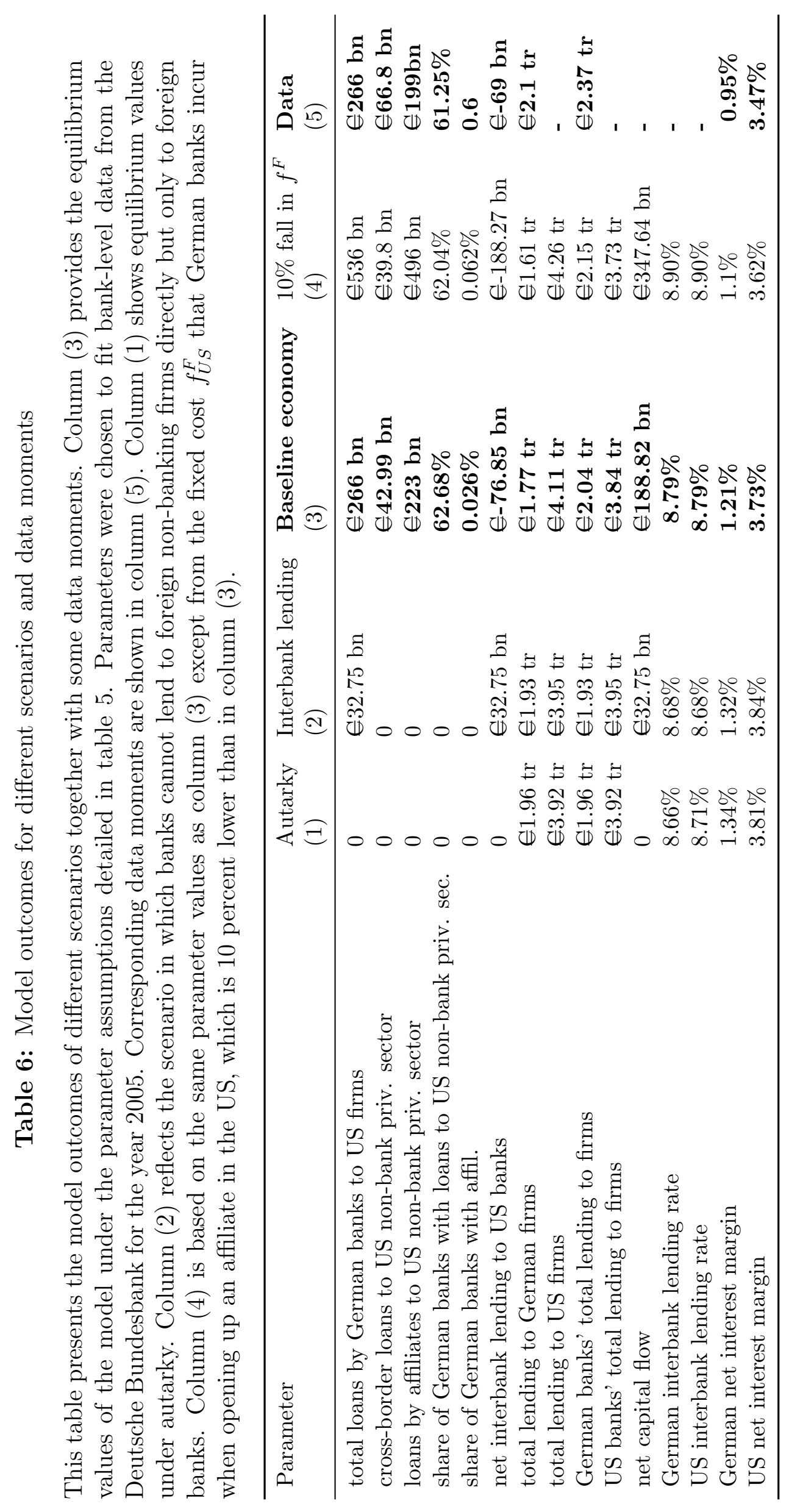




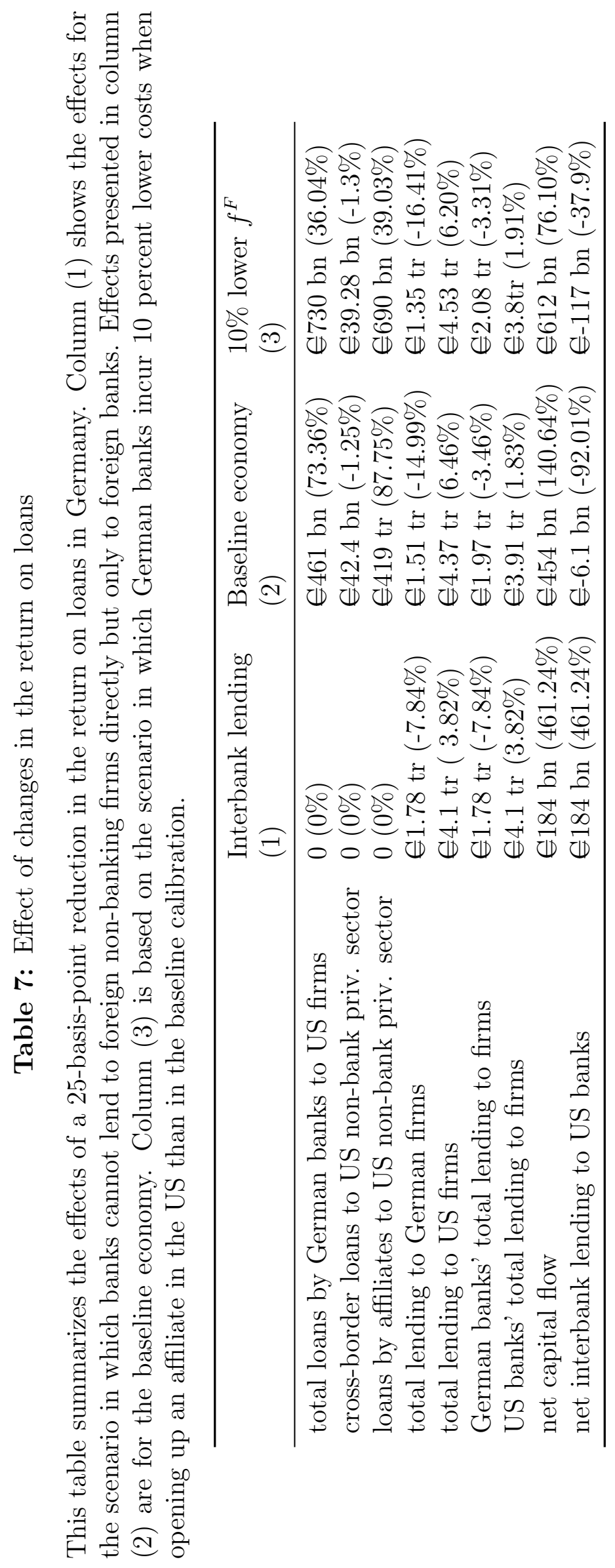


Table 8: Sectoral composition of foreign bank positions by openness of destination country This table tests whether there are systematic differences in the composition of German banks' positions across countries with different degrees of openness. We split countries into three similarly large groups (high, middle, low openness) according to their Chinn-Ito Index, bureaucratic quality and property rights protection. We then compare the log ratio of banks' average claims on banks over their average claims on the non-bank private sector $\ln ($ ClaimsBvP) across groups (high versus low openness). Calculations are based on data from the Deutsche Bundesbank for 2005. Standard errors are in parentheses. ${ }^{* * *} \mathrm{p}<0.01,{ }^{* *} \mathrm{p}<0.05,{ }^{*} \mathrm{p}<0.1$.

\begin{tabular}{lccc}
\hline & High & Low & Difference \\
\hline Chinn-Ito openness index & & & \\
Range of index & {$[2.262 ; 2.532]$} & {$[-1.812 ;-1.131]$} & \\
No. of countries in group & 54 & 60 & \\
& & & \\
Obs. (No. of banks in group) & 5756 & 296 & $-0.902^{* * *}$ \\
Mean of ln(ClaimsBvP) & -0.386 & 0.516 & $(0.178)$ \\
St. Err. & $(0.039)$ & $(0.206)$ & \\
& & & \\
\hline Bureaucratic quality & & & \\
Range of index & {$[3 ; 4]$} & {$[0 ; 1.54]$} & \\
No. of countries in group & 45 & 41 & \\
& & & \\
Obs. (No. of banks in group) & 6005 & 158 & \\
Mean of ln(ClaimsBvP) & -0.368 & 0.004 & $-0.372^{*}$ \\
St. Err. & $(0.039)$ & $(0.301)$ & $(0.247)$ \\
& & & \\
\hline Property rights protection & & & \\
Range of index & {$[70 ; 90]$} & {$[10 ; 30]$} & \\
No. of countries in group & 37 & 73 & \\
Obs. (No. of banks in group) & 5878 & 418 & \\
Mean of ln(ClaimsBvP) & -0.322 & -0.027 & $-0.294^{* *}$ \\
St. Err. & $(0.04)$ & $(0.184)$ & $(0.156)$ \\
\hline
\end{tabular}


Figure 1: The sectoral composition of international bank claims held by BIS reporting countries, 1999-2013

The upper chart shows the evolution of total international bank claims of BIS reporting countries over time split by sector. The lower chart depicts the share of claims on the foreign non-bank private sector and the share of claims on the foreign banking sector in total international claims. The data source are the BIS Consolidated Statistics. Claims are on an immediate borrower basis and exclude local claims.

The sectoral composition of international claims

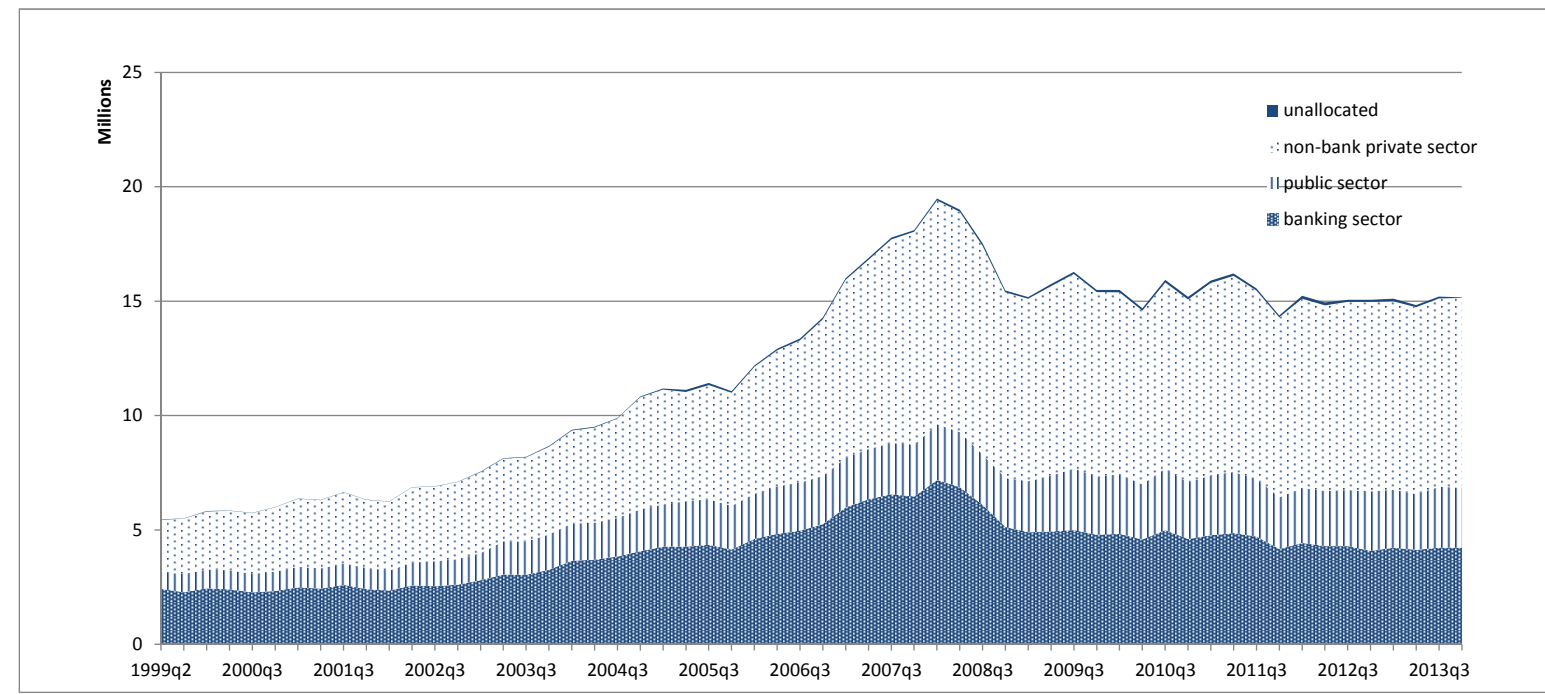

Shares in total international claims by sector

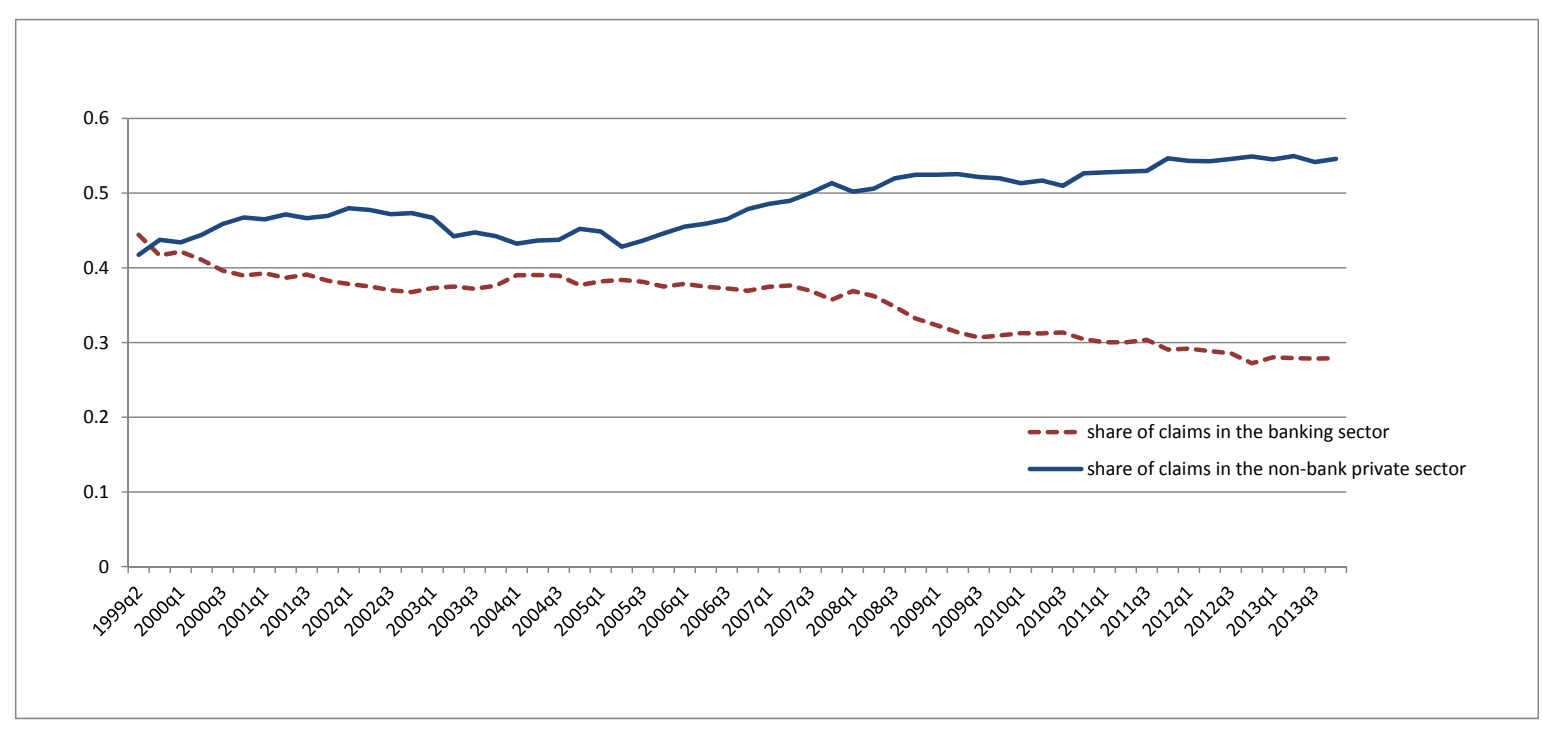


Figure 2: The distribution of bank efficiency a

This graph shows the distribution of the bank-specific efficiency measure $a$. The smallest and largest 5th percentiles are not displayed. The calculation of $a$ is based on bank-level data (in $€ 1,000)$ from the Deutsche Bundesbank for 2005.

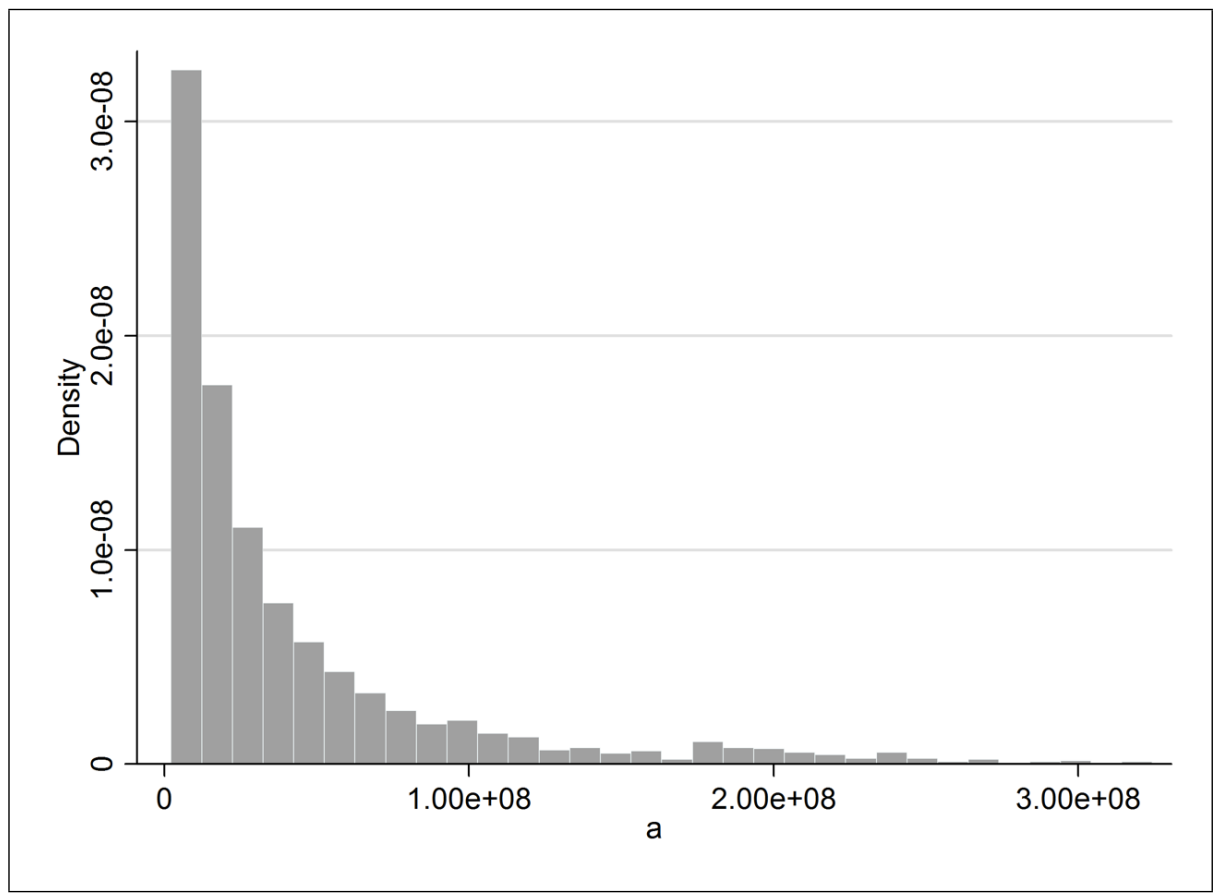


Figure 3: Bank efficiency $a$ as a predictor of cross-border lending

This chart shows the distribution of rank correlation coefficients across host countries between the following two rankings: each bank's rank based on the size of its cross-border lending to country $i$ and its rank based on the size of its domestic lending. The rank correlation coefficient for each country indicates how well a bank's domestic lending predicts its cross-border lending to the respective country. The line that overlays the histogram depicts the corresponding kernel density estimate. Some countries are listed exemplarily across the distribution near the histogram bin into which their correlation coefficient falls. Data used in the calculations are from the Deutsche Bundesbank and for the year 2005.

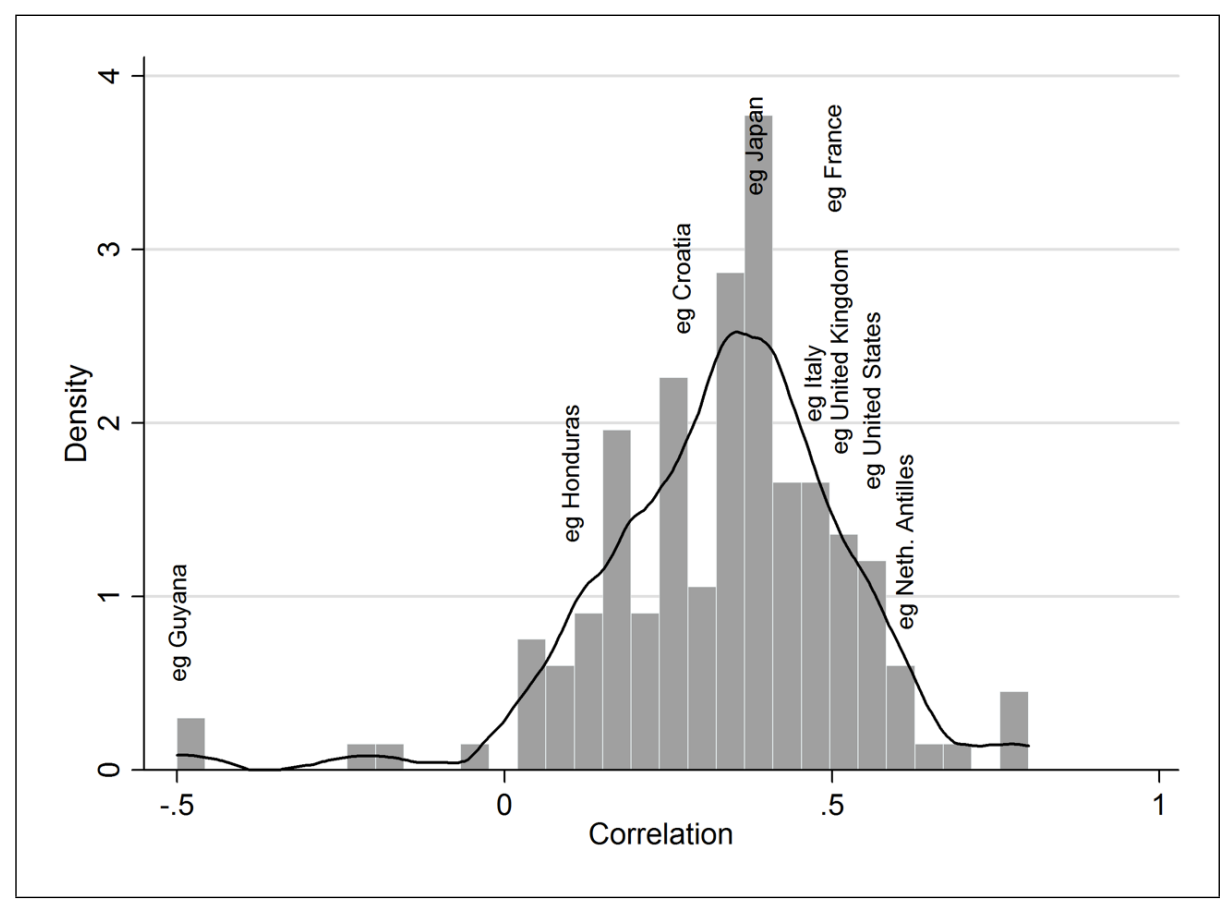


Figure 4: The relationship between domestic and foreign lending volumes This chart plots banks' cross-border lending to the non-bank private sector of country $i$ as a function of bank efficiency $a_{b}$ using an artificial dataset (original bank-level data cannot be shown due to confidentiality). Arrows depict the effect from multiplying $a_{b}$ with $\phi_{b i}$.

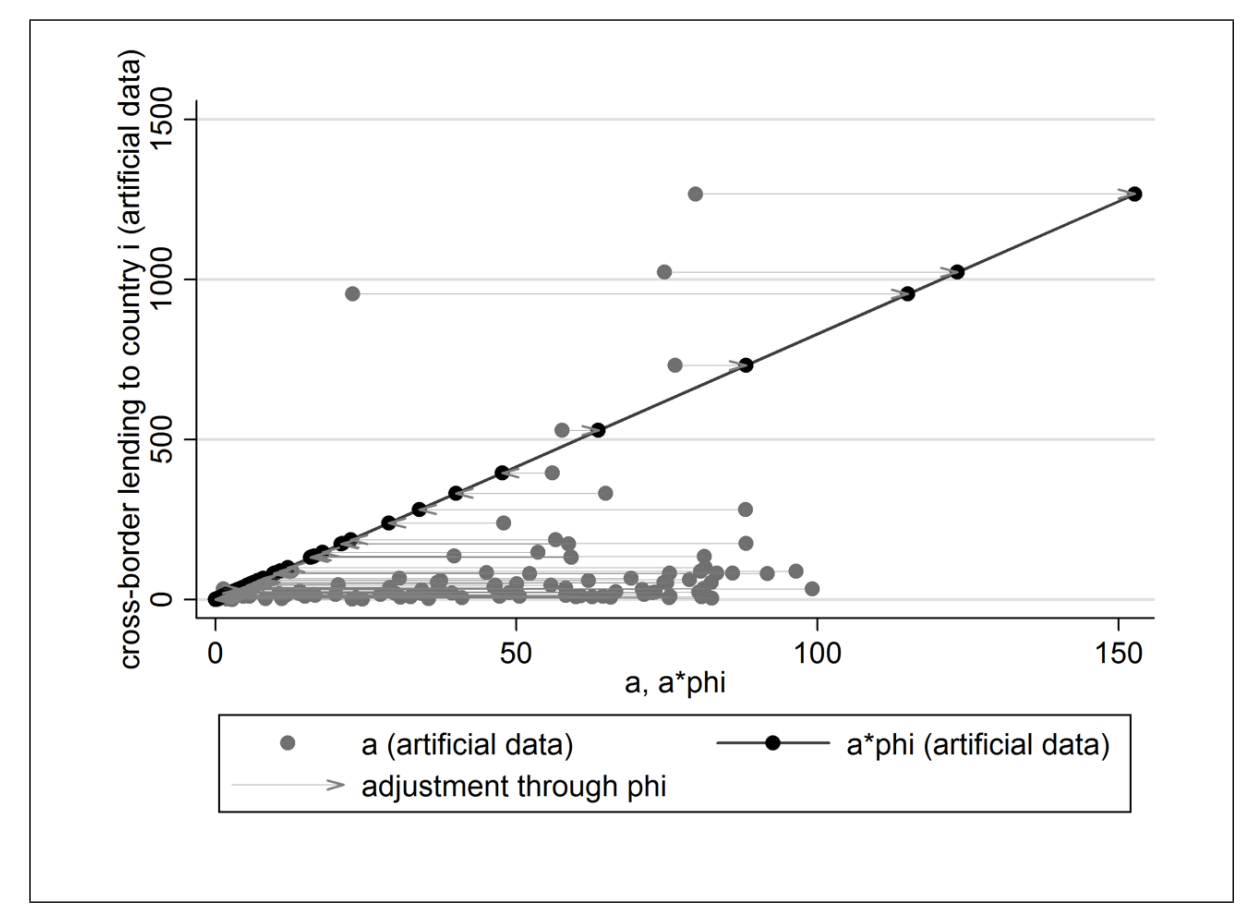


Figure 5: Bank efficiency $a$ as a predictor of net interbank lending

This chart plots the estimated relationship between German banks' net interbank claims and bank efficiency $a_{b}$ obtained from a simple OLS regression together with the 95th percent confidence interval. The 5 th and the 95 th percentiles of the bank efficiency distribution are excluded from the estimation. Net interbank claims are in $€ 1,000$. Data used in the calculations are from the Deutsche Bundesbank and for the year 2005.

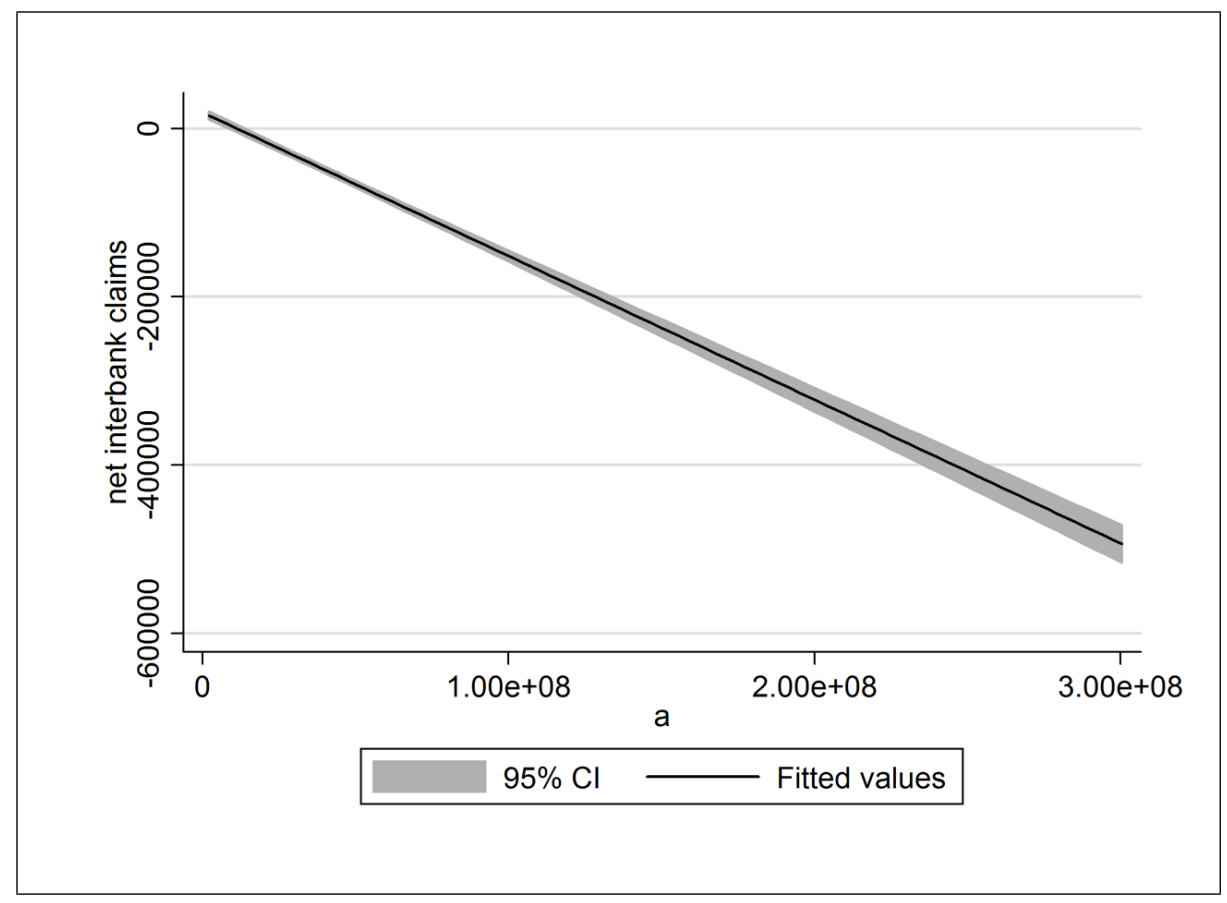


Figure 6: Counterfactual analysis

This table illustrates the composition of German banks' foreign assets, their funding sources, and bank flows between Germany and the US in the model. Each of the three charts in the figure shows outcomes for three different scenarios. The bars on the left capture scenario (i) in which German and US banks can only lend and borrow from each other on the international interbank market. The bars in the middle show outcomes for scenario (ii), which corresponds to the baseline economy that is calibrated based on the parameters presented in table 5. The bars on the right hand side assume that the fixed cost of establishing an affiliate in the US $f^{F}$ is 10 percent lower than in the baseline economy (scenario iii). The top chart shows the composition of German bank loans in the US, which are split into loans to US banks, loans to US firms extended by German parent banks and loans to US firms extended by local affiliates of US parent banks. The chart in the middle summarizes how German banks' US assets are funded. Funding comes either from German depositors, US depositors or US banks. The bottom chart illustrates the composition of international bank flows between Germany and the US. Banks flows consist of intrabank flows between German parent banks and their US affiliates, interbank flows between German and US banks as well as cross-border flows from parent banks to US non-banking firms.
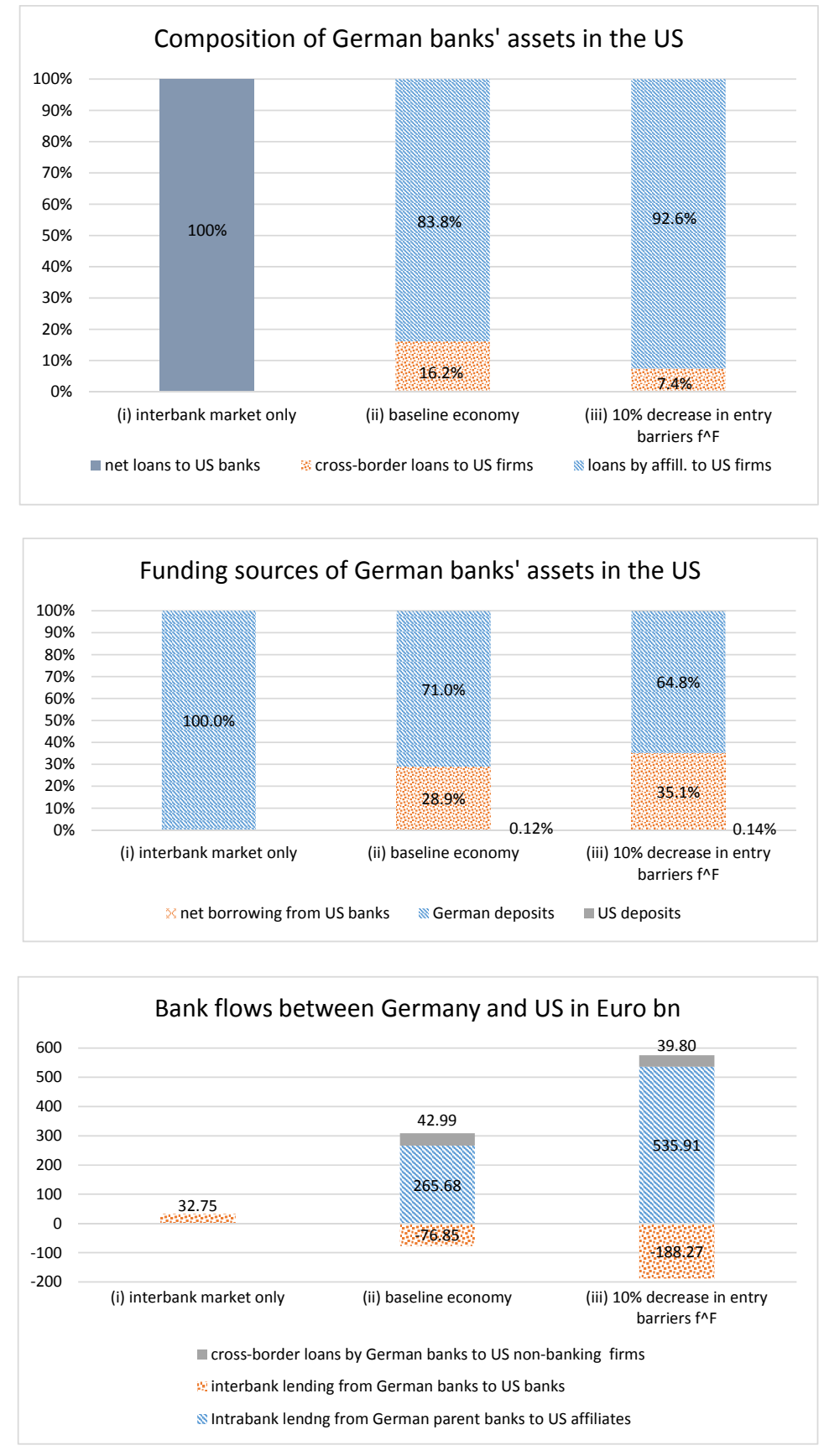